\title{
MERCURY SPECIATION SAMPLING AT NEW CENTURY ENERGY'S VALMONT STATION
}

\author{
Final Report
}

Prepared for:

National Energy Technology Laboratory

AAD Document Control

U.S. Department of Energy

P.O. Box 10940, Ms 921-143

Pittsburgh, PA 15236-0940

Performance Monitor: Richard Read

Contract NO.: DE-FC26-98FT40321--07 


\section{DISCLAIMER}

This report was prepared as an account of work sponsored by an agency of the United States Government. Neither the United States Government, nor any agency thereof, nor any of their employees makes any warranty, express or implied, or assumes any legal liability or responsibility for the accuracy, completeness, or usefulness of any information, apparatus, product, or process disclosed or represents that its use would not infringe privately owned rights. Reference herein to any specific commercial product, process, or service by trade name, trademark, manufacturer, or otherwise does not necessarily constitute or imply its endorsement, recommendation, or favoring by the United States Government or any agency thereof. The views and opinions of authors expressed herein do not necessarily state or reflect those of the United States Government or any agency thereof.

This report is available to the public from the National Technical Information Service, U.S. Department of Commerce, 5285 Port Royal Road, Springfield, VA 22161; phone orders accepted at (703) 487-4650.

\section{EERC DISCLAIMER}

LEGAL NOTICE This research report was prepared by the Energy \& Environmental Research Center (EERC), an agency of the University of North Dakota, as an account of work sponsored by EPRI, Great River Energy, and the U.S. Department of Energy. Because of the research nature of the work performed, neither the EERC nor any of its employees makes any warranty, express or implied, or assumes any legal liability or responsibility for the accuracy, completeness, or usefulness of any information, apparatus, product, or process disclosed, or represents that its use would not infringe privately owned rights. Reference herein to any specific commercial product, process, or service by trade name, trademark, manufacturer, or otherwise does not necessarily constitute or imply its endorsement or recommendation by the EERC. 


\section{TABLE OF CONTENTS}

LIST OF FIGURES $\ldots \ldots \ldots \ldots \ldots \ldots \ldots \ldots \ldots \ldots \ldots \ldots \ldots \ldots \ldots \ldots \ldots \ldots$

LIST OF TABLES $\ldots \ldots \ldots \ldots \ldots \ldots \ldots \ldots \ldots \ldots \ldots \ldots \ldots \ldots \ldots \ldots \ldots \ldots \ldots$

EXECUTIVE SUMMARY $\ldots \ldots \ldots \ldots \ldots \ldots \ldots \ldots \ldots \ldots \ldots \ldots \ldots \ldots$

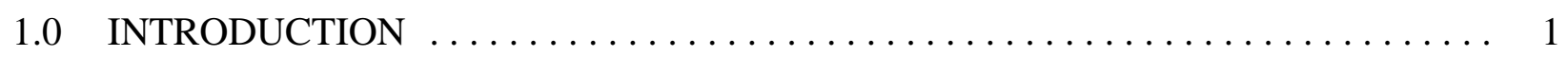

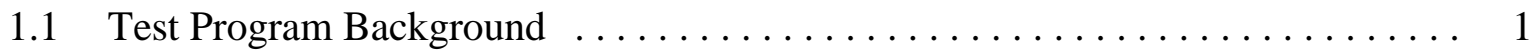

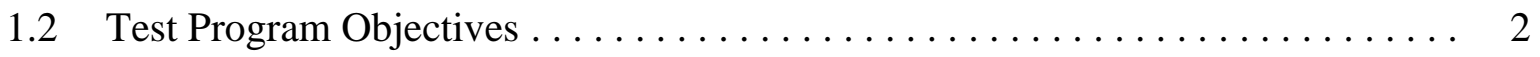

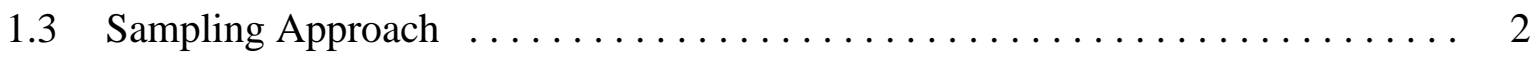

2.0 PROCESS DESCRIPTIONS $\ldots \ldots \ldots \ldots \ldots \ldots \ldots \ldots \ldots \ldots \ldots \ldots \ldots \ldots \ldots \ldots$

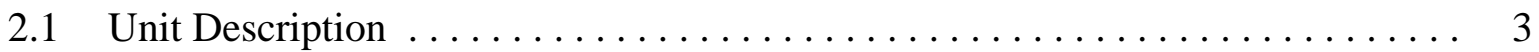

2.2 Sampling Test Plan, Locations, and Collection Procedures . . . . . . . . 5

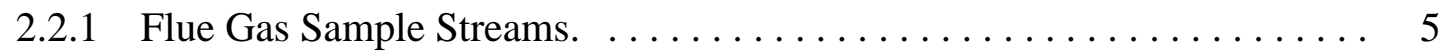

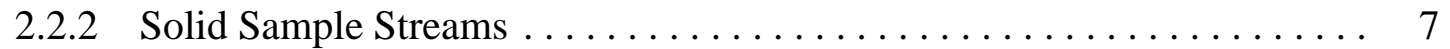

2.3 Process Operation During Testing $\ldots \ldots \ldots \ldots \ldots \ldots \ldots \ldots \ldots \ldots \ldots \ldots \ldots \ldots \ldots$

3.0 FLUE GAS SAMPLING AND ANALYTICAL METHODS $\ldots \ldots \ldots \ldots \ldots \ldots \ldots$

3.1 Ontario Hydro Mercury Speciation Method . . . . . . . . . . . . . . . . 11

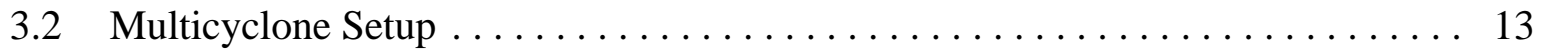

3.3 EPA Method $26 \mathrm{~A} \ldots \ldots \ldots \ldots \ldots \ldots \ldots \ldots \ldots \ldots \ldots \ldots \ldots$

3.4 Determination of Coal and Ash Mercury $\ldots \ldots \ldots \ldots \ldots \ldots \ldots \ldots \ldots \ldots$

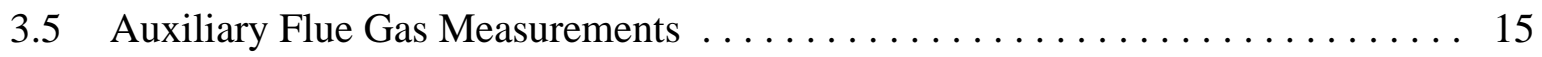

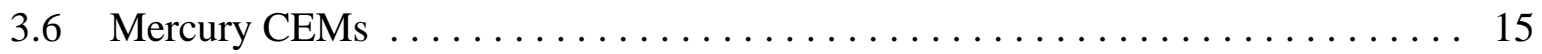

4.0 MERCURY MEASUREMENT RESULTS $\ldots \ldots \ldots \ldots \ldots \ldots \ldots \ldots \ldots \ldots$

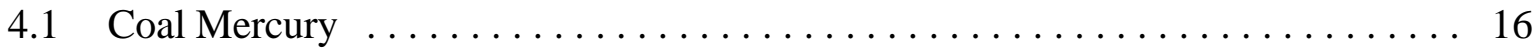

4.2. Baghouse Hopper Ash, Sample Filter, and Multicyclone . . . . . . . . . . . 17

4.3 Flue Gas Mercury Speciation Results . . . . . . . . . . . . . . . . . . . 19

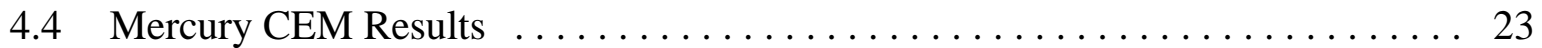

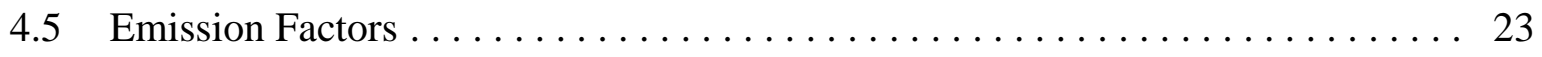

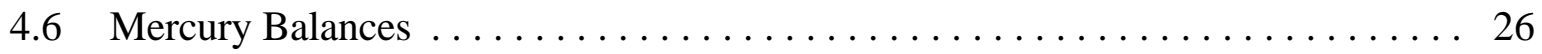

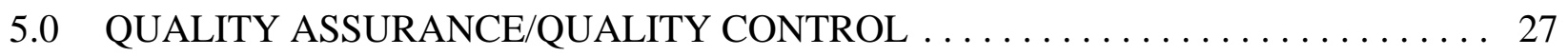

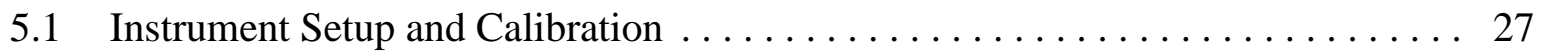

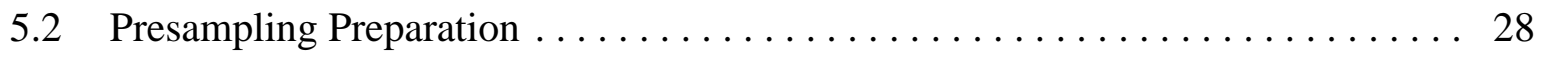

5.3 Glassware and Plasticware Cleaning and Storage $\ldots \ldots \ldots \ldots \ldots \ldots \ldots \ldots$

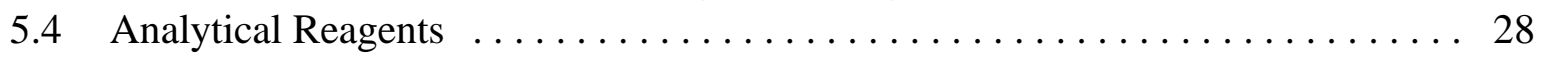

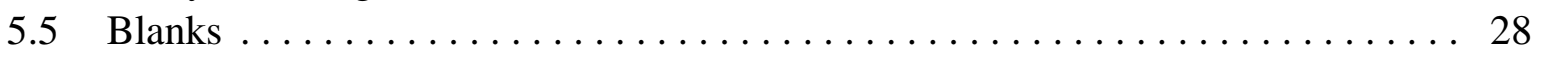




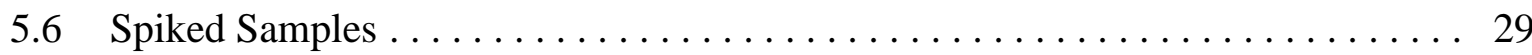

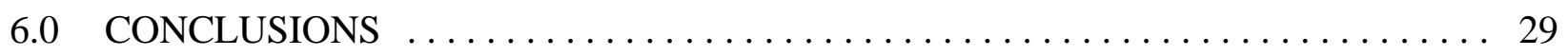

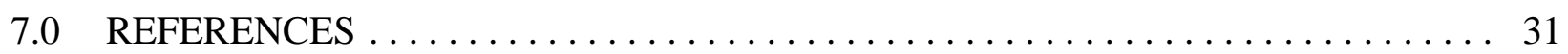

EXAMPLES OF CALCULATIONS USED IN THE REPORT $\ldots \ldots \ldots \ldots \ldots$ Appendix A

\section{LIST OF FIGURES}

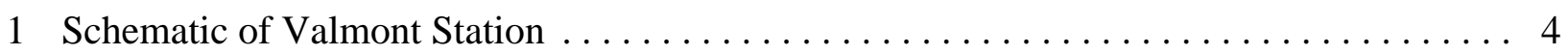

2 Illustration of the baghouse inlet sampling location $\ldots \ldots \ldots \ldots \ldots \ldots \ldots \ldots$

3 Illustration of the stack sampling location $\ldots \ldots \ldots \ldots \ldots \ldots \ldots \ldots \ldots \ldots \ldots \ldots \ldots \ldots$

4 Schematic of the Ontario Hydro mercury speciation sampling train $\ldots \ldots \ldots \ldots \ldots \ldots 12$

5 Sample recovery scheme for Ontario Hydro mercury speciation sampling train . . . . . . 12

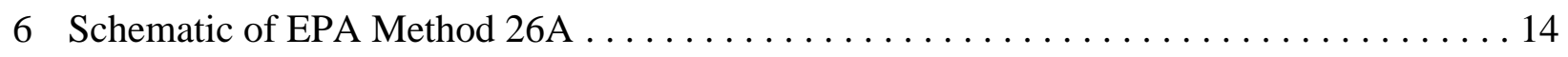

7 Particle-size distribution at the inlet to baghouse $\ldots \ldots \ldots \ldots \ldots \ldots \ldots \ldots \ldots \ldots \ldots \ldots \ldots$

8 Effect of particle size on the concentration of particulate-bound mercury $\ldots \ldots \ldots \ldots \ldots$

9 Effect of the baghouse on speciated mercury concentration $\ldots \ldots \ldots \ldots \ldots \ldots \ldots \ldots$

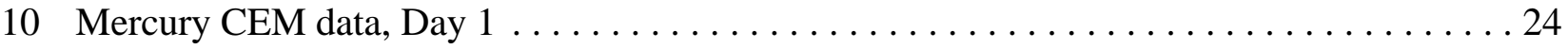

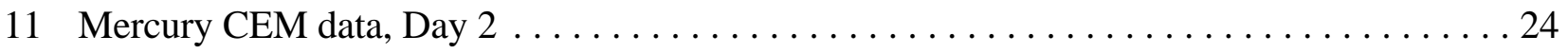




\section{LIST OF TABLES}

1 Mercury Speciation Test Program Matrix at Unit 10 Valmont Station ............ 3

2 Baghouse Particulate Collection Efficiency $\ldots \ldots \ldots \ldots \ldots \ldots \ldots \ldots \ldots \ldots \ldots \ldots \ldots \ldots$

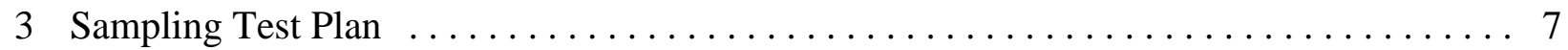

4 Analysis of the Colorado Bituminous Coal $\ldots \ldots \ldots \ldots \ldots \ldots \ldots \ldots \ldots$

5 XRF Analysis of the Baghouse Hopper Ash $\ldots \ldots \ldots \ldots \ldots \ldots \ldots \ldots \ldots$

6 Valmont Station Operating Conditions Summary $\ldots \ldots \ldots \ldots \ldots \ldots \ldots \ldots \ldots$

7 Average Excess Oxygen and Moisture Content at Mercury Speciation Sampling Points $\ldots \ldots \ldots \ldots \ldots \ldots \ldots \ldots \ldots \ldots \ldots \ldots \ldots \ldots \ldots \ldots \ldots$

8 Sample Train Components - EPA Method 17 Configuration $\ldots \ldots \ldots \ldots \ldots \ldots \ldots$

9 Mercury in the Coal from the Valmont Station $\ldots \ldots \ldots \ldots \ldots \ldots \ldots \ldots \ldots \ldots$

10 Comparison of Mercury Concentration in ESP Ash and Sample Filters . . . . . . . . . 18

11 Mercury Concentration in Multicyclone Stages and Backup Filter . . . . . . . . . . . . . 19

12 Mercury Speciation Results for Unit V5 Valmont Station $\ldots \ldots \ldots \ldots \ldots \ldots \ldots$

13 Average Partitioning of Flue Gas Mercury Species in Unit $10 \ldots \ldots \ldots \ldots \ldots \ldots$

14 Mercury Speciation Results at the Inlet to the Air Preheater . . . . . . . . . . . 21

15 Comparison of Mercury Speciation Results, Multicyclone versus Filter . . . . . . . . . 22

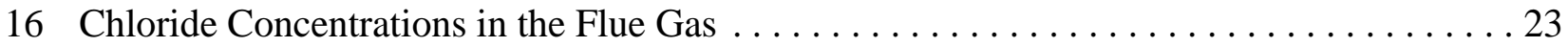

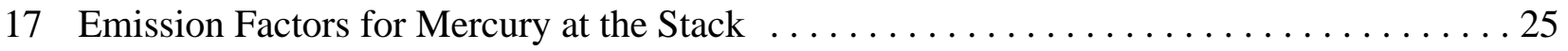

18 Mercury Emission Factors at the Stack, Comparison of Calculation Methods . . . . . . . 25

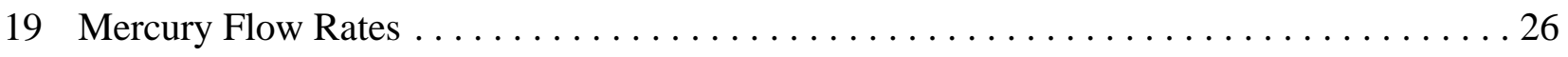




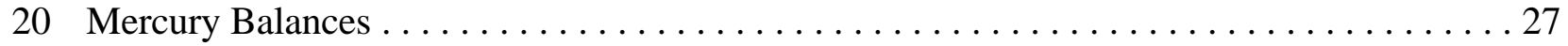

21 Reagent Blank Analysis Results . . . . . . . . . . . . . . . . . . . . . . . . . 29

22 Results of Mercury Speciation Field Blanks $\ldots \ldots \ldots \ldots \ldots \ldots \ldots \ldots \ldots \ldots \ldots \ldots$

23 Results of Mercury Speciation Field Spikes $\ldots \ldots \ldots \ldots \ldots \ldots \ldots \ldots \ldots \ldots \ldots \ldots \ldots \ldots$ 


\section{MERCURY SPECIATION SAMPLING AT NEW CENTURY ENERGY'S VALMONT STATION}

\section{EXECUTIVE SUMMARY}

The 1990 Clean Air Act Amendments required the U.S. Environmental Protection Agency (EPA) to determine whether the presence of mercury in the stack emissions from fossil fuel-fired electric utility power plants poses an unacceptable public health risk. EPA's conclusions and recommendations were presented in the Mercury Study Report to Congress and Study of Hazardous Air Pollutant Emissions from Electric Utility Steam Generating Units. The first report addressed both the human health and environmental effects of anthropogenic mercury emissions, while the second addressed the risk to public health posed by the emission of mercury and other hazardous air pollutants from steam electric generating units. Although these reports did not state that mercury controls on coalfired electric power stations would be required given the current state of the art, they did indicate that the EPA views mercury as a potential threat to human health. Therefore, it was concluded that mercury controls at some point may be necessary. EPA also indicated that additional research/information was necessary before any definitive statement could be made.

In an effort to determine the amount and types of mercury being emitted into the atmosphere by coal-fired power plants, EPA in late 1998 issued an information collection request (ICR) that required all coal-fired power plants to analyze their coal and submit the results to EPA on a quarterly basis. In addition, about 85 power stations were required to measure the speciated mercury concentration in the flue gas. These plants were selected on the basis of plant configuration and coal type. The Valmont Station owned and operated by New Century Energy in Boulder, Colorado, was selected for detailed mercury speciation of the flue gas as part of the ICR process. New Century Energy, in a tailored collaboration with EPRI and the U.S. Department of Energy, contracted with the Energy \& Environmental Research Center (EERC) to do a study evaluating the behavior of mercury at the Valmont Station. The activities conducted at the Valmont Station by the EERC not only included the sampling needed to meet the requirements of the ICR, but involved a much more extensive mercury research program.

\section{Test Program Objectives}

The following objectives for the sampling at New Century Energy's Valmont Station were accomplished:

- Successfully complete all of the mercury sampling and reporting requirements of the ICR.

- Determine the variability in mercury concentrations at the stack using mercury continuous emission monitors (CEMs).

- Calculate mercury mass balances and emission rates. 
- Determine the mercury concentration in the fly ash as a function of particle size.

- Determine the impact of a fabric filter on mercury emissions for a western bituminous coal.

\section{Approach}

Flue gas sampling was completed at Unit V5 at the Valmont Station to determine the mercury speciation across the baghouse and the concentration (and species) of mercury leaving the stack. Sampling was completed using the Ontario Hydro $(\mathrm{OH})$ mercury speciation method at the inlet to the baghouse and at the stack. Another major objective of the program was to evaluate the ability of mercury CEMs to measure mercury at a full-scale unit. Therefore, at the Valmont Station, four mercury CEMs were used to continuously measure the mercury in the stack.

\section{Results}

Figure ES-1 presents graphically the results of the mercury sampling for the Valmont Station. This figure clearly shows that the fabric filter effectively removed the particulate-bound and elemental mercury. It is also clear that the mercury concentrations at the stack are very low, as shown by the emission factors in Table ES-1. Even though the mercury concentrations at this plant were very low, reasonable mercury balances were obtained, as shown in Table ES-2.

\section{Conclusions}

On the basis of the results from the sampling program at the Valmont Station, the following conclusions can be made:

- The mercury emissions (stack) from UnitV5 at the Valmont Station are very low, $>0.2 \mu \mathrm{g} / \mathrm{Nm}^{3}$.

- The baghouse captured $~ 85 \%$ of the total mercury generated and over $95 \%$ of the particulate-bound mercury and $\mathrm{Hg}^{0}$.

- The Semtech Hg 2000/2010 results were not very good because of the very low mercury concentrations at the stack. However, the PS Analytical Sir Galahad and Tekran gave total mercury results very comparable to those obtained using the Ontario Hydro mercury speciation sampling method.

- The total mercury emission factors, based on the coal feed rate, was only $0.17 \pm 0.15 \mathrm{lb} / 10^{12}$ Btu.

- Although the mercury concentrations were very low, the overall mercury balance and mercury balance across the baghouse were good, $118.3 \%$ and $70.5 \%$, respectively. 


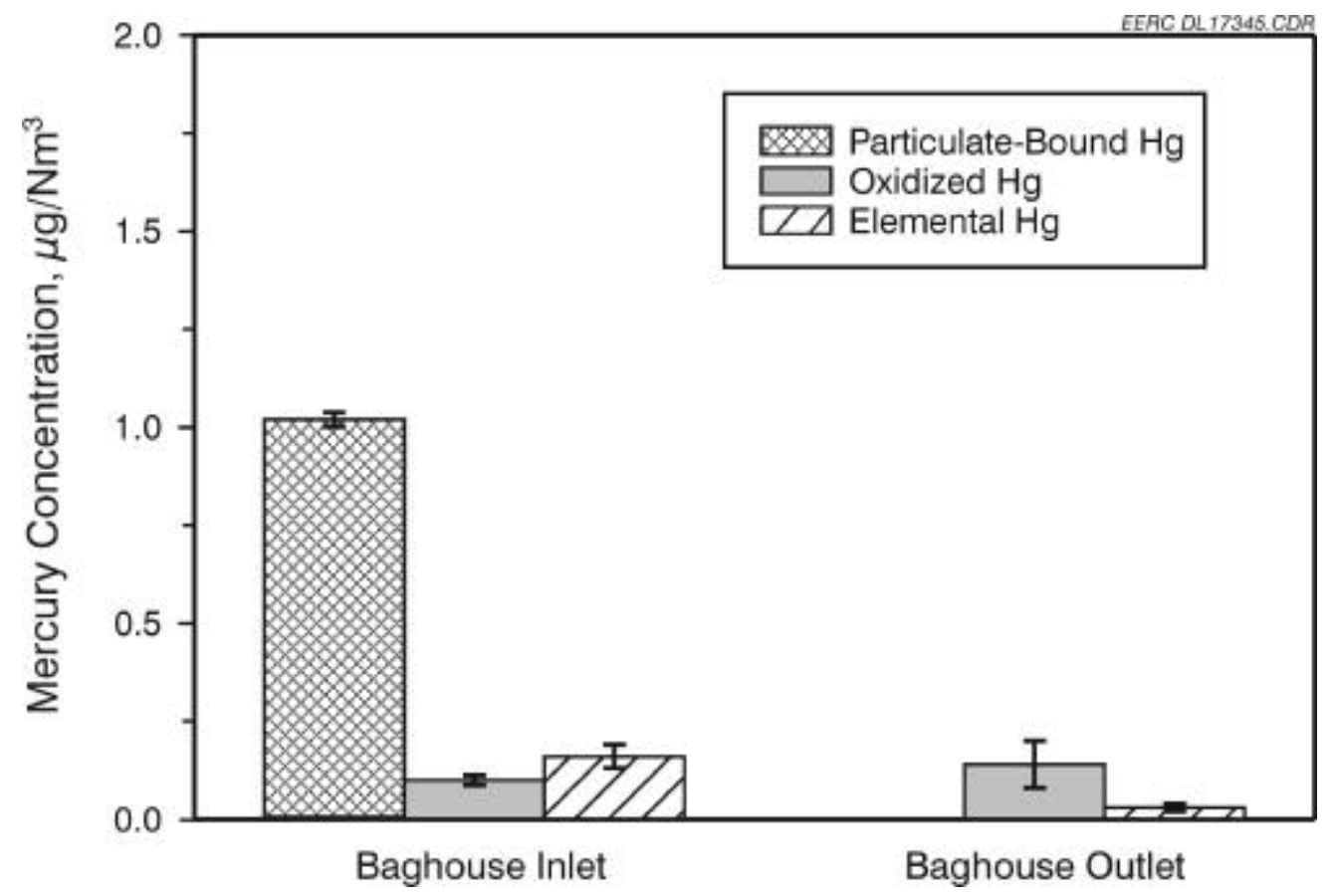

Figure ES-1. Effect of the baghouse on speciated mercury concentration.

- The fly ash generated at the Valmont Station resulted in mercury being adsorbed across the filter of the $\mathrm{OH}$ sampling method at the inlet of the baghouse. This adsorption was greatly reduced using a multicyclone rather than a filter.

- The sampling results indicate that the Valmont Station should be able to meet almost any mercury regulation that would be proposed without any changes to the system.

TABLE ES-1

Emission Factors for Mercury at the Stack

\begin{tabular}{ccccc}
\hline & \multicolumn{4}{c}{ Emission Factors, $\mathbf{~ b b / 1 0} \mathbf{1 0}^{\mathbf{1 2}} \mathbf{B t u}$} \\
\cline { 2 - 5 } Run & Particulate- & \multicolumn{3}{c}{ Hg $^{\mathbf{0}}$} \\
\hline 1 & $<0.002$ & 0.10 & 0.03 & 0.12 \\
2 & $<0.002$ & 0.08 & 0.02 & 0.09 \\
3 & $<0.002$ & 0.19 & 0.04 & 0.22 \\
\hline Average & $<0.002$ & 0.12 & 0.03 & 0.15 \\
Std. Dev & NA $^{1}$ & 0.06 & 0.01 & 0.07 \\
\hline
\end{tabular}


${ }^{1}$ Not applicable. 


\section{TABLE ES-2}

Mercury Balances

\begin{tabular}{lcc}
\hline Run & Overall, $\boldsymbol{\%}^{1}$ & $\begin{array}{c}\text { Across the Baghouse, } \\
\boldsymbol{\%}^{1}\end{array}$ \\
\hline 1 & 100.0 & 86.7 \\
2 & 85.7 & 40.0 \\
3 & 160.0 & 80.0 \\
Average & 115.2 & 68.9 \\
\hline${ }^{1}$ Outlet/inlet. & &
\end{tabular}




\section{MERCURY SPECIATION SAMPLING AT NEW CENTURY ENERGY'S VALMONT STATION}

\subsection{INTRODUCTION}

\subsection{Test Program Background}

The 1990 Clean Air Act Amendments required the U.S. Environmental Protection Agency (EPA) to determine whether the presence of mercury in the stack emissions from fossil fuel-fired electric utility power plants poses an unacceptable public health risk. EPA's conclusions and recommendations were presented in the Mercury Study Report to Congress (1) and Study of Hazardous Air Pollutant Emissions from Electric Utility Steam Generating units (2). The first report addressed both the human health and environmental effects of anthropogenic mercury emissions, while the second addressed the risk to public health posed by the emission of mercury and other hazardous air pollutants from steam electric generating units. Although these reports did not state that mercury controls on coalfired electric power stations would be required given the current state of the art, they did indicate that the EPA views mercury as a potential threat to human health. Therefore, it was concluded that mercury controls at some point may be necessary. EPA also indicated that additional research/information was necessary before any definitive statement could be made.

In an effort to determine the amount and types of mercury being emitted into the atmosphere by coal-fired power plants, EPA in late 1998 issued an information collection request (ICR) (3). Two primary activities required by the ICR impacted the coal-fired electric utility industry. First, all coal-fired plants were required to submit to EPA, on a quarterly basis, coal analyses. These analyses were to include the following:

- $\quad$ Mercury concentration, ppm (by weight)

- $\quad$ Chlorides, ppm (by weight)

- Ash content, \% (by weight)

- $\quad$ Sulfur, \% (by weight)

- Heating value, btu/lb

Second, about 85 power stations were required to measure the speciated mercury concentration in the flue gas. These plants were selected on the basis of plant configuration and coal type. The Valmont Station owned and operated by New Century Energy, in Boulder, Colorado, was selected for detailed mercury speciation of the flue gas as part of the ICR process. New Century Energy, as part of a tailored collaboration with EPRI and the U.S. Department of Energy contracted with the EERC to do a study evaluating the behavior of mercury at the Valmont Station. The activities conducted at the 
Valmont Station by the EERC not only included the sampling needed to meet the requirements of the ICR, but involved a much more extensive mercury research program.

\subsection{Test Program Objectives}

The following objectives for the sampling at New Century Energy's Valmont Station were accomplished:

- $\quad$ Provide the utility a site-specific test plan and quality assurance/quality control (QA/QC) project plan that allowed the utility to meet the requirements of the ICR.

- $\quad$ Successfully complete all of the mercury sampling, using the Ontario Hydro $(\mathrm{OH})$ mercury speciation method, and reporting as required by the ICR. Note: The ICR report has been submitted to the EPA. (Copies were supplied to all the project participants).

- Determine the variability in mercury concentrations at the stack using mercury continuous emission monitors (CEMs).

- $\quad$ Calculate mercury mass balances and emission rates.

- $\quad$ Determine the mercury concentration in the fly ash as a function of particle size.

- $\quad$ Determine the effect of the residence time (length of time the ash is on the fabric filter bags) on the concentration of particulate-bound mercury.

\subsection{Sampling Approach}

Table 1 identifies the mercury-sampling test program matrix. Representative samples were collected and analyzed for mercury from each of the targeted flue gas streams and solid streams.

Samples were taken to generate the following data:

- $\quad$ Particulate-bound, oxidized $\left(\mathrm{Hg}^{2+}\right)$, and elemental $\left(\mathrm{Hg}^{0}\right)$ mercury emissions at the inlet and outlet (stack) of the fabric filter using the $\mathrm{OH}$ speciation method.

- $\quad$ Mercury and chlorine content of representative coal samples collected from the coal feeders.

- $\quad$ Mercury content of a composite fly ash sample from the baghouse hoppers.

- $\quad$ Gas-phase mercury concentrations at the stack location using mercury CEMs concurrently with the $\mathrm{OH}$ mercury speciation method sampling. 
TABLE 1

Mercury Speciation Test Program Matrix at Unit 10 Valmont Station

\begin{tabular}{lcc}
\hline & $\begin{array}{c}\text { Target Mercury Samples } \\
\text { Speciated Hg } \\
\text { Process Stream }\end{array}$ & $\begin{array}{c}\text { Torticulate-bound, } \\
\left.\mathbf{H g}^{2+} \text {, and } \mathbf{H g}^{\mathbf{0}}\right)\end{array}$ \\
\hline Flue Gas Sample Streams & $\mathrm{X}$ & $\mathrm{X}$ \\
Fabric Filter Inlet & $\mathrm{X}$ & $\mathrm{X}$ \\
Baghouse Outlet (stack) & $\mathrm{X}$ & $\mathrm{X}$ \\
Air Preheater & & $\mathrm{X}$ \\
Solid Samples & $\mathrm{X}$ \\
Coal Feeders (composite of the feeders) & \\
Baghouse Hopper & & \\
\hline
\end{tabular}

- $\quad$ Particulate-bound, $\mathrm{Hg}^{2+}$, and $\mathrm{Hg}^{0}$ concentrations at the inlet and outlet of the fabric filter using a multicyclone-modified $\mathrm{OH}$ mercury speciation method.

\subsection{PROCESS DESCRIPTIONS}

This section describes the Valmont Station and the various sample locations that were used for the test program. The process operation during testing is also described. During the testing, the unit at the Valmont Station was at or near nominal full load at steady-state operation, and all equipment, including coal feeders, boilers, and fabric filter were all within normal operating ranges.

\subsection{Unit Description}

The Valmont Station is located in Boulder Valley of Colorado on 900+ acres near three surrounding lakes. The plant, which was originally built in 1924, now consists of two units. The first Unit (V5) fires a low-sulfur Colorado bituminous coal. The second Unit (V6) uses natural gas as a fuel. The plant, owned and operated by New Century Energy, has a total generating capacity of $231 \mathrm{MW}$ and supplies electricity to customers in Colorado. The V5 unit that was the focus of the project has a nameplate rating of $166 \mathrm{MW}$ and went into service in 1964.

Coal for the Valmont Station, which comes by rail, is a Colorado bituminous coal from the Eagle or 20-Mile mine. The total amount of coal burned per year at the Valmont Station is about 550,000 tons. The coal is crushed prior to being shipped to the plant. Once the coal is at the plant site, it is 
stored in coal piles and is conveyed to the four pulverizing mills. The mills pulverize the coal to approximately $65 \%$ through a 200 -mesh screen. The pulverized coal is fed to the boilers pneumatically and injected into the furnace through the burners. The coal feed rate is measured at the coal feeders, and the weighing system is calibrated quarterly. Fuel samples were collected from the coal feeders located just prior to the pulverizers that feed directly into the boilers.

The Valmont Station boiler, manufactured by Combustion Engineering, is tangentially fired, with a gross heat input of $1750 \times 10^{6} \mathrm{Btu} / \mathrm{hr}$. The particulate matter from Unit V5 boiler is removed by a reverse-gas fabric filter. Figure 1 shows an overall schematic of the Unit V5 boiler, baghouse, and stack.

Key unit parameters include the following:

- $\quad$ Unit capacity: approximately $189 \mathrm{MW}$ gross

- $\quad$ Boiler type: tangentially fired

- $\quad$ Fuel type: Colorado bituminous (Eagle and 20-Mile mine)

- $\mathrm{SO}_{2}$ control: none

- Particulate control: reverse-gas fabric filter

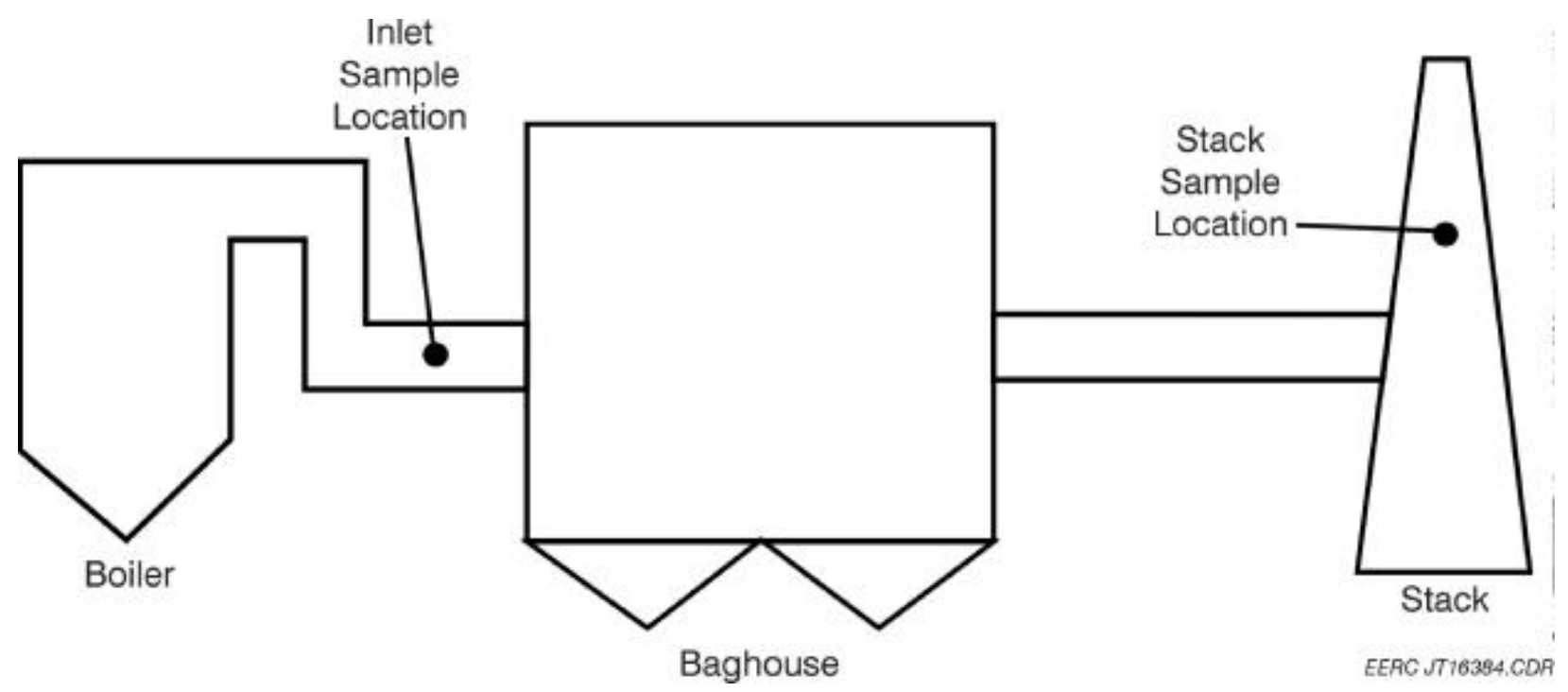

Figure 1. Schematic of Valmont Station. 
- $\quad \mathrm{NO}_{\mathrm{x}}$ control: low-NOx burners

The fabric filter has a reverse-gas cleaning mechanism and uses woven fiberglass bags. The baghouse has 16 compartments with 400 bags per compartment. Each bag is $34 \mathrm{ft}$ long and 0.12 in. in diameter and operates at a nominal air-to-cloth ratio of $2 \mathrm{ft} / \mathrm{min}$. However the actual operating air-tocloth ratio is closer to 1.7. The actual particulate collection efficiency during the testing is shown in Table 2 . The collection efficiency was calculated by using the dust loading measured at the inlet to the baghouse and the dust loading at the stack. As Table 2 shows, the measured particulate collection efficiency during the testing period was generally above the minimum specifications. Unit V5 meets the Federal Environmental Emission Standard of $0.1 \mathrm{lb}$ of particulate matter per million Btu input. The fly ash collected in the baghouse hoppers is landfilled.

\section{TABLE 2}

Baghouse Particulate Collection Efficiency

\begin{tabular}{lccc}
\hline Run & $\begin{array}{c}\text { Inlet } \\
\text { Dust Loading, } \\
\text { grains/scf }\end{array}$ & $\begin{array}{c}\text { Baghouse Outlet } \\
\text { Dust Loading, } \\
\text { grains/scf }\end{array}$ & $\begin{array}{c}\text { Baghouse Particulate } \\
\text { Collection Efficiency, } \\
\text { \% }\end{array}$ \\
\hline 1 & 2.2318 & 0.0028 & 99.87 \\
2 & 1.9452 & 0.0203 & 98.96 \\
3 & 2.4463 & 0.0017 & 99.93 \\
Average & 2.2078 & 0.0083 & 99.63 \\
\hline
\end{tabular}

\subsection{Sampling Test Plan, Locations, and Collection Procedures}

\subsubsection{Flue Gas Sample Streams}

The flue gas flow splits immediately after exiting the boiler; however, the ducts rejoin prior to fabric filter. The inlet sampling location was at the common duct. After exiting the fabric filter the flue gas again is split until it exits at the stack. Therefore all the sampling done for this project represents the entire gas stream. The sampling locations are represented by solid circles in Figures 2 and 3.

As part of the ICR sampling effort, it was required that mercury mass balances be obtained across the baghouse. Therefore, it was necessary to measure the flue gas mercury at the inlet of the baghouse, as well as at the stack. Not only is it important to measure total mercury at the stack, but also the mercury speciation, because the rate of deposition of mercury in the environment is highly dependent on the type of mercury being emitted (4). Also, measurement of mercury speciation at the inlet allows the 
determination of species removal and/or transformations across the baghouse. As stated earlier, all mercury speciation sampling was done using the $\mathrm{OH}$ method. 


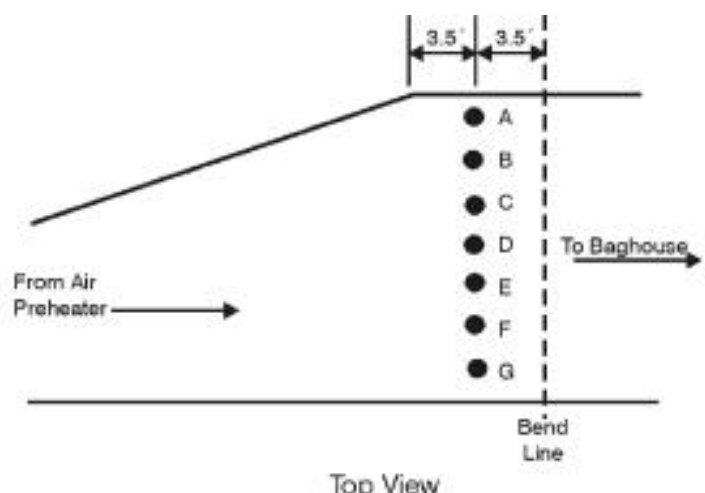

Top View

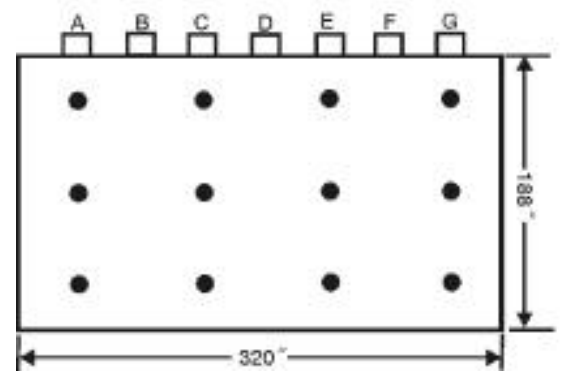

\begin{tabular}{|r|c|}
\hline $\begin{array}{c}\text { Teat Port } \\
\text { Traverse } \\
\text { Point }\end{array}$ & $\begin{array}{c}\text { Oistance from } \\
\text { Inside neas } \\
\text { Wakd (in) }\end{array}$ \\
\hline A. C, E, G, -1 & 32 \\
2 & 94 \\
3 & 156 \\
\hline
\end{tabular}

Figure 2. Illustration of the baghouse inlet sampling location.

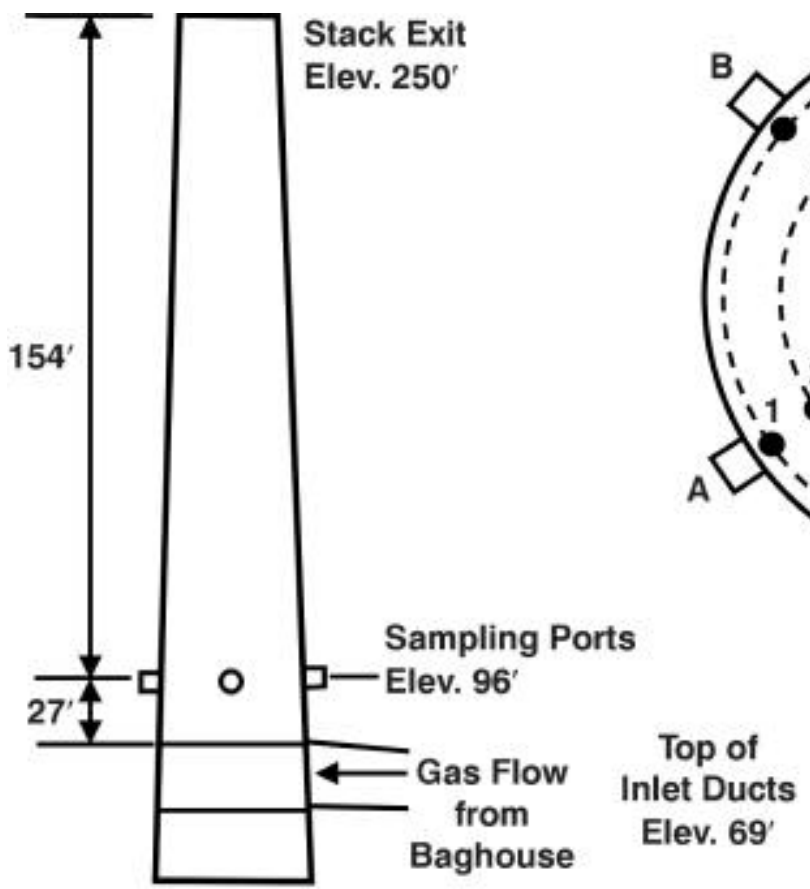

\begin{tabular}{|r|c|}
\hline Traverse & $\begin{array}{c}\text { Distance } \\
\text { from } \\
\text { Inside Wall (in.) }\end{array}$ \\
\hline A, B, C, D - 1 & 12 \\
2 & 39 \\
3 & 79 \\
\hline
\end{tabular}

Figure 3. Illustration of the stack sampling location. 
It was intended that the sampling follow the EPA Method 1 protocols; however, at the baghouse inlet location, there was a duct system expansion too close to the baghouse sampling port, and at the stack, the sampling ports were located too close to the inlet. Therefore, it was not possible to meet all the EPA Method 1 sampling criteria at either sampling location. Although the sample ports at the inlet location are not ideal, an expansion following the sampling points was not expected to greatly impact the air flow patterns or the ability to isokinetically sample the gas stream. At the stack, the mercury was very near $100 \%$ in the gas phase and, therefore, not impacted by uncertainties in gas flow and isokinetic sampling rate. At both sampling locations, a 12-point traverse in $4 \times 3$ grid was done as specified in the test plan. At all locations, the gas temperature was above the minimum filter temperature (248EF) as stated by the $\mathrm{OH}$ method. Consequently, EPA Method 17 sampling procedures (in-stack filtration) were used.

Other flue sampling that was done at Unit V5 at the Valmont Station in addition to that required by the ICR, including $\mathrm{OH}$ sampling at the air preheater, $\mathrm{OH}$ sampling with a five-stage multicyclone, mercury CEM sampling at the stack, and EPA Method 26A to determine the chloride concentrations in the flue gas. The sampling at the air preheater location was to determine the impact of temperature on concentration of particulate-bound mercury and also speciated gaseous mercury. The multicyclone sampling was to measure the particulate-bound mercury concentration as a function of particle size. The flue gas sampling test plan for the project is presented in Table 3.

\section{TABLE 3}

Sampling Test Plan

\begin{tabular}{|c|c|c|c|c|}
\hline Location & $\begin{array}{c}\text { No. of } \mathrm{OH} \\
\text { Samples }\end{array}$ & $\begin{array}{l}\text { Sampling } \\
\text { Grid }\end{array}$ & $\begin{array}{c}\text { Temperature, } \\
\text { EF }\end{array}$ & $\begin{array}{c}\text { Particulate Collection } \\
\text { Method }\end{array}$ \\
\hline Baghouse Inlet & 3 & $4 \times 3$ & 297 & EPA Method 17 \\
\hline Baghouse Inlet & 3 & $4 \times 3$ & 289 & $\begin{array}{l}\text { Five-Stage } \\
\text { Multicyclone }\end{array}$ \\
\hline $\begin{array}{l}\text { Air Preheater } \\
\text { Outlet }\end{array}$ & 3 & Single point & 767 & EPA Method 17 \\
\hline Stack $^{1}$ & 3 & $4 \times 3$ & 284 & EPA Method 17 \\
\hline EPA Method 26A & 2 & Single point & 298 & EPA Method 17 \\
\hline
\end{tabular}

\subsubsection{Solid Sample Streams}

In an effort to substantiate the flue gas mercury data, coal feed and baghouse hopper ash were sampled. These samples were analyzed for total mercury, and, along with the flue gas emissions data, 
were used to calculate the mercury mass balances. Coal samples were collected just prior to the four individual pulverizing mills during each of the three flue gas sampling periods. In accordance with ASTM procedures, 16 individual coal samples (four from each mill) were collected during each 2-hour sampling period. The 16 individual samples collected from each mill were composited, resulting in a total of three coal samples, one from each sampling period. Analyses completed on each coal were ultimate, proximate, Btu, chlorides, and mercury analyses. As shown in Table 4, the coal burned at the Valmont plant is very low in mercury and sulfur.

\section{TABLE 4}

Analysis of the Colorado Bituminous Coal ${ }^{1}$

\begin{tabular}{lccc}
\hline Run & $\mathbf{1}$ & $\mathbf{2}$ & $\mathbf{3}$ \\
\hline Mercury and Chlorides & & & \\
$\quad$ Mercury, ppm (dry) & 0.010 & 0.0055 & 0.0083 \\
$\quad$ Chlorides (Cl), ppm (dry) & $<50$ & 66 & $<50$ \\
Proximate Analysis, wt\% & & & \\
$\quad$ Moisture Content & 16.10 & 16.30 & 12.10 \\
$\quad$ Volatile Matter & 35.57 & 35.01 & 37.47 \\
$\quad$ Fixed Carbon & 41.62 & 41.78 & 42.72 \\
$\quad$ Ash & 6.71 & 6.91 & 7.70 \\
Ultimate Analysis, wt\% & & & \\
$\quad$ Hydrogen & 5.66 & 5.56 & 5.53 \\
Carbon & 58.31 & 57.32 & 61.54 \\
$\quad$ Nitrogen & 1.85 & 1.79 & 1.97 \\
$\quad$ Sulfur & 0.25 & 0.25 & 0.43 \\
Oxygen, by difference & 27.22 & 28.18 & 22.83 \\
$\quad$ Ash & 6.71 & 6.91 & 7.70 \\
Heating Value & & & \\
Btu/lb & 10,317 & 10,250 & 10,207 \\
\hline${ }^{1}$ As-received unless otherwise noted. & & &
\end{tabular}

On the basis previous mercury sampling done at the Valmont Station, it was expected that this coal would produce a fly ash that readily adsorbed mercury. Therefore, it was an important part of this test to determine what impact the fabric filter had on particulate-bound mercury. To help facilitate this, all the bags were cleaned and the hoppers emptied just prior to each flue gas mercury sample. Then once the $\mathrm{OH}$ flue gas sample was completed, the bags were again cleaned and a sample was taken from each of the baghouse hoppers. The ash samples were analyzed for mercury using cold-vapor atomic absorption (CVAA) and for major and some trace elements using X-ray fluorescence (XRF) analyses. The results of these analyses are shown in Table 5. 
TABLE 5

XRF Analysis of the Baghouse Hopper Ash

\begin{tabular}{lccc}
\hline Run & $\mathbf{1}$ & $\mathbf{2}$ & $\mathbf{3}$ \\
\hline Major Elements, \% as oxides & & & \\
$\quad$ Silicon & 58.2 & 58.3 & 59.6 \\
Calcium & 5.37 & 5.47 & 4.44 \\
Aluminum & 25.5 & 25.3 & 27.1 \\
Iron & 4.34 & 4.44 & 3.10 \\
Magnesium & 1.51 & 1.56 & 1.60 \\
Sulfur & 0.083 & 0.046 & 0.00 \\
Sodium & 1.54 & 1.48 & 1.20 \\
$\quad$ Potassium & 1.00 & 0.99 & 1.11 \\
Minor Elements, \% as oxides & & & \\
Barium & 0.43 & 0.43 & 0.29 \\
Strontium & 0.25 & 0.25 & 0.23 \\
Titanium & 0.93 & 0.93 & 0.80 \\
Phosphorus & 0.84 & 0.83 & 0.50 \\
$\quad$ Manganese & 0.024 & 0.025 & 0.013 \\
Trace Elements & & $\mathrm{mg} / \mathrm{kg}$ & \\
Mercury & & & \\
Zinc & 0.132 & 0.071 & 0.141 \\
Chromium & 100 & 100 & $<100$ \\
Nickel & $<100$ & $<100$ & $<100$ \\
Vanadium & $<100$ & $<100$ & $<100$ \\
Copper & 110 & 101 & $<100$ \\
\hline
\end{tabular}

${ }^{1}$ Mercury as $\mathrm{Hg}^{0}$ was analyzed using CVAA techniques.

\subsection{Process Operation During Testing}

Table 6 summarizes the process operating conditions and gas emissions during the mercury speciation test program for Unit V5 at the Valmont Station. As this table shows, operation during this test program was representative of normal daily operation at or near full load, and there was little variation during the test program. $\mathrm{SO}_{2}$ and particulate emissions were in compliance, with no operating problems identified.

The target excess $\mathrm{O}_{2}$ at the boiler exit was to be $3.0 \% \pm 0.5 \%$. As Table 6 shows, the unit fell within this range. The average excess $\mathrm{O}_{2}$ for the three sampling periods was $3.1 \% \pm 0.06 \%$. The average $\mathrm{O}_{2}$ levels and moisture content at each of the flue gas sampling points are shown in Table 7. These $\mathrm{O}_{2}$, data indicate a substantial air leak across the air preheater and the various expansion joints.

TABLE 6 


\section{Valmont Station Operating Conditions Summary}

\begin{tabular}{lccc}
\hline Run & $\mathbf{1}$ & $\mathbf{2}$ & $\mathbf{3}$ \\
\hline Process Conditions & & & \\
$\quad$ Net Load, MW & 181 & 181 & 176 \\
Total Coal Feed Rate, Klb/hr & 156 & 155 & 139 \\
Gas Flow at the Stack, scfm & 422,604 & 458,007 & 449,222 \\
Main Steam Flow, Klb/hr & 1246 & 1247 & 1250 \\
Air Preheater Inlet Temp, EF & 729 & 731 & 714 \\
Stack Gas Temp., EF & 274 & 281 & 298 \\
Baghouse Inlet Gas Temp., EF & 292 & 294 & 3.11 \\
Plant CEMs & & & \\
Boiler $\mathrm{O}_{2}, \%$ & 3.0 & 3.0 & 3.2 \\
Stack $\mathrm{CO}_{2}, \%$ & 12.2 & 11.8 & 11.2 \\
Exit $\mathrm{NO}_{\mathrm{x}}$ Emissions, lb/10 $10^{6} \mathrm{Btu}$ & 0.23 & 0.25 & 0.28 \\
Exit $\mathrm{SO}_{2}$ Emissions, lb/10 $\mathrm{Btu}$ & 0.43 & 0.43 & 0.64 \\
Opacity, \% & 3.31 & 3.04 & 2.88 \\
\hline
\end{tabular}

TABLE 7

Average Excess Oxygen and Moisture Content at Mercury Speciation Sampling Points

\begin{tabular}{lcc}
\hline Sample Location & $\begin{array}{c}\text { Excess } \mathbf{O}_{\mathbf{2}} \\
\text { (on a dry basis), } \\
\mathbf{\%}\end{array}$ & $\begin{array}{c}\text { Moisture } \\
\text { Content, } \\
\mathbf{\%}\end{array}$ \\
\hline Boiler & 3.1 & 8.7 \\
Baghouse Inlet & 5.4 & 9.2 \\
Stack & 5.4 & 6.7 \\
\hline
\end{tabular}

\subsection{FLUE GAS SAMPLING AND ANALYTICAL METHODS}

This section describes the methods and analytical procedures that were used for the test program to determine the mercury speciation and chlorides in the flue gas, as well as the total mercury in the solid and liquid streams of the plant. The details of all the EPA sampling procedures discussed in this section (EPA Methods 1-4, 5, 17, 29, 26A, and the OH method) can be found on the EPA's Emission Measurement Center Web Site at the address http://www.epa.gov/ttn/emc. 
One issue that has been extensively discussed with respect to mercury speciation methods is the temperature at which the particulate filter should be maintained. On the basis of current procedures, the requirement is that the filter and sample probe be maintained at the flue gas temperature or a minimum of $248 \mathrm{EF}$. The best way to ensure that the filter and probe are maintained at the flue gas temperature is to use in-stack filtration (EPA method 17) procedures. For all the $\mathrm{OH}$ method flue gas sampling that was done at Valmont, EPA Method 17 was used.

\subsection{Ontario Hydro Mercury Speciation Method}

The mercury speciation method used to conduct this project is entitled Standard Test Method for Elemental, Oxidized, Particle-Bound and Total Mercury in Flue Gas Generated from CoalFired Stationary Sources (Ontario Hydro Mercury Speciation Method). This method was developed jointly by Dr. Keith Curtis and the EERC. It was subsequently validated by the EERC at both the pilotand full-scale level (5). The method is currently being reviewed by the American Society for Testing Materials (ASTM) Subcommittee D22.03.01 and was the mercury speciation method required for the ICR.

In the $\mathrm{OH}$ method, using the sampling procedures outlined in EPA Methods 1-4 and EPA Method 17 or Method 5, a sample is withdrawn from the flue gas stream isokinetically through the filtration system, which is followed by a series of impingers in an ice bath. Particulate-bound mercury is collected on the front half and filter; oxidized mercury $\left(\mathrm{Hg}^{2+}\right)$ is collected in impingers containing $1 \mathrm{~N}$ potassium chloride $(\mathrm{KCl})$ solution; and elemental mercury $\left(\mathrm{Hg}^{0}\right)$ is collected in one impinger containing a $5 \% \mathrm{v} / \mathrm{v}$ nitric acid $\left(\mathrm{HNO}_{3}\right)$ and $10 \% \mathrm{v}$, hydrogen peroxide $\left(\mathrm{H}_{2} \mathrm{O}_{2}\right)$ solution and in three impingers containing a solution of $10 \% \mathrm{v} / \mathrm{v}$ sulfuric acid $\left(\mathrm{H}_{2} \mathrm{SO}_{4}\right)$ and $4 \% \mathrm{w} / \mathrm{v}$ potassium permanganate $\left(\mathrm{KMnO}_{4}\right)$. An impinger containing silica gel collects any remaining moisture. Quartz fiber filters were used as the filter medium for the testing, and the filter holder was glass. A heated Teflon line connected the probe and impinger train. A target sampling time of 2 hours was used, with a target sample volume of 1 to 2.5 standard cubic meters. Schematics of the sample train and the recovery procedures are shown in Figures 4 and 5. Table 8 presents a list of sample train components for the EPA Method 17 configuration.

All glassware for the sample trains was precleaned using a 4-hr soak in a $10 \% \mathrm{v} / \mathrm{HNO} \mathrm{HO}_{3}$ solution, with no impinger glassware used more than once during the field test. Samples collected using the Ontario Hydro method were recovered into the following fractions:

- Container 1 - the sample filter

- Container 2 - the front half rinse (includes all surfaces upstream of the filter)

- Container 3 - Impingers 1 through 3 ( $\mathrm{KCl}$ impingers) and rinses

- Container 4 - Impinger $4\left(\mathrm{HNO}_{3}-\mathrm{H}_{2} \mathrm{O}_{2}\right.$ impinger $)$ and rinses 


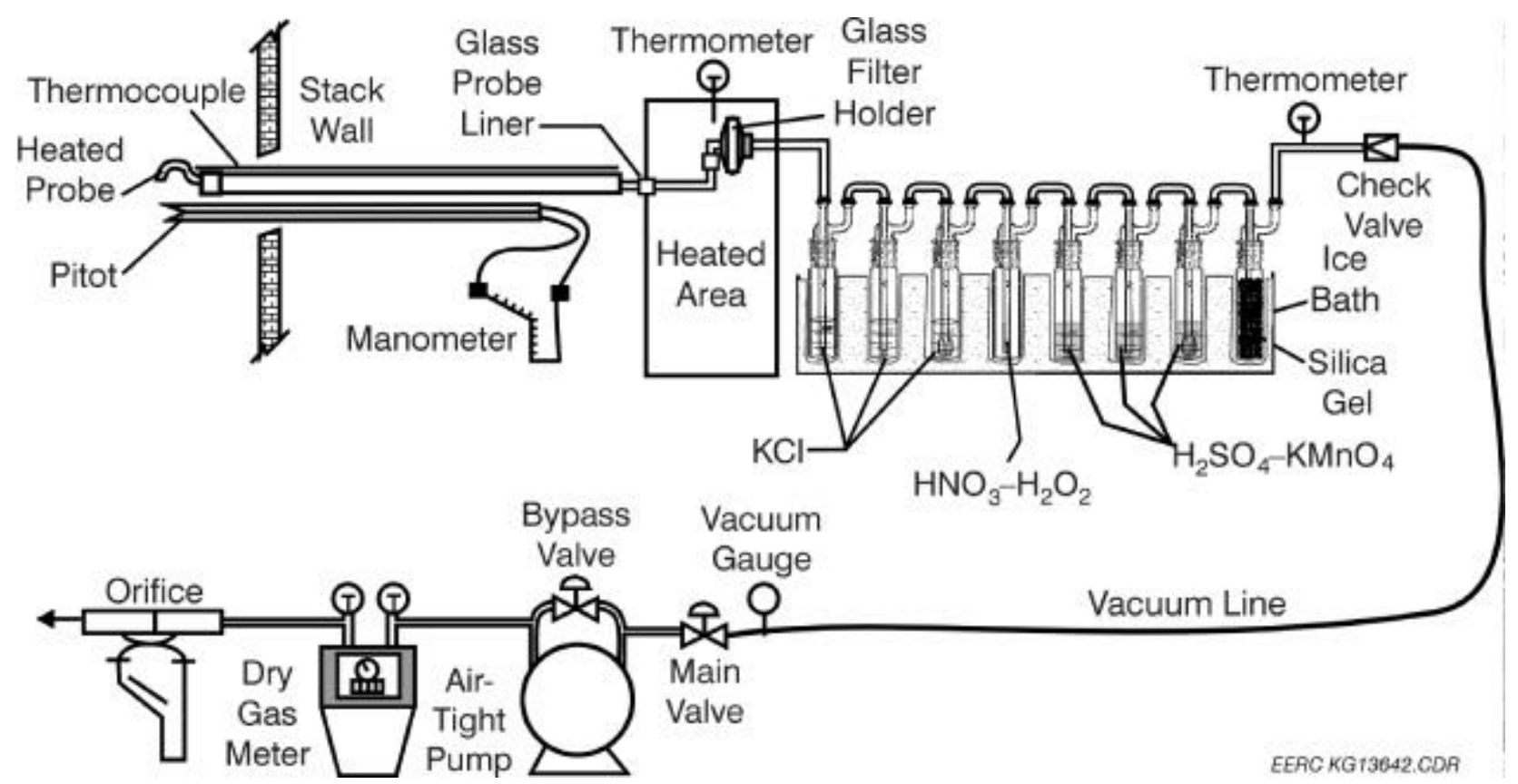

Figure 4. Schematic of the Ontario Hydro mercury speciation sampling train.

1. Rinse filter holder and connector with $0.1 \mathrm{~N} \mathrm{HNO}_{3}$.

2. Add $5 \% \mathrm{w} / \mathrm{v} \mathrm{KMnO}_{4}$ to each impinger bottle until purple color remains.

3. Rinse with $10 \% \frac{v}{v} \mathrm{HNO}_{3}$.

4. Rinse with a very small amount of $10 \% \mathrm{w} / \mathrm{v}$ Rinse Bottles Sparingly with

$\mathrm{NH}_{2} \mathrm{OH} \cdot \mathrm{H}_{2} \mathrm{SO}_{4}$ if brown residue remains. $\quad-0.1 \mathrm{~N} \mathrm{HNO}_{3}$

5. Final rinse with $10 \% \%_{v} \mathrm{HNO}_{3}$. $-10 \% \% / v \mathrm{NH}_{2} \mathrm{OH} \cdot \mathrm{H}_{2} \mathrm{SO}_{4}$

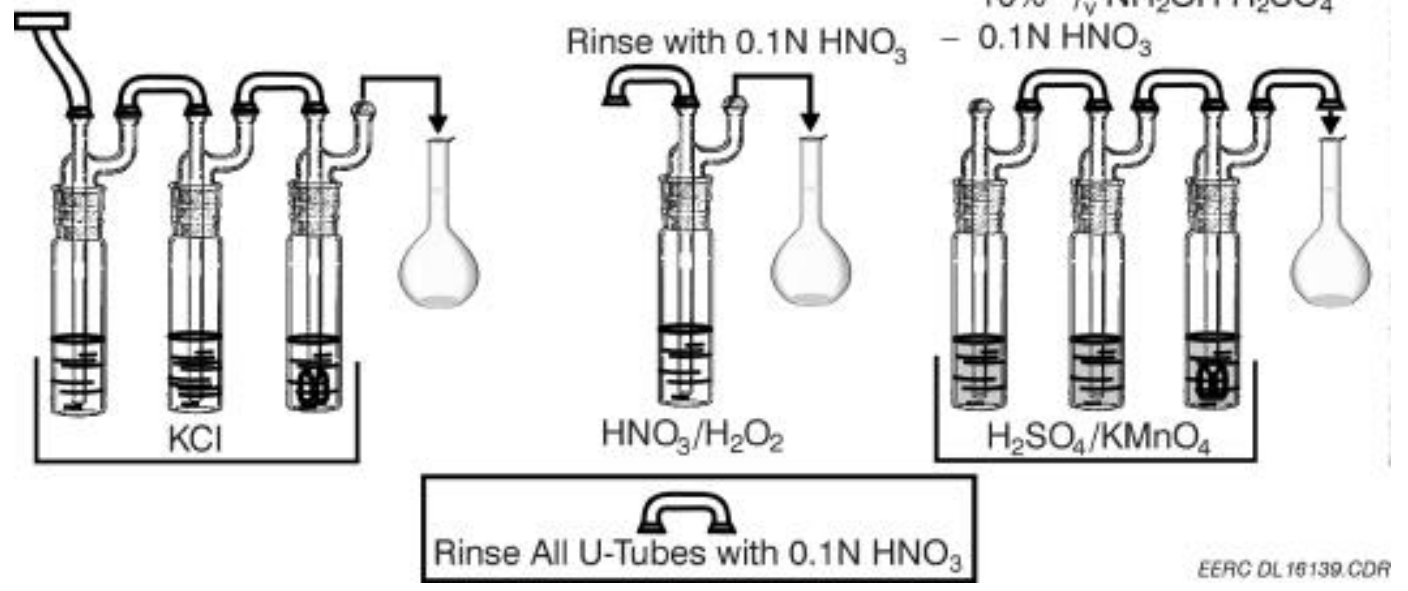

Figure 5. Sample recovery scheme for Ontario Hydro mercury speciation sampling train. 
TABLE 8

Sample Train Components - EPA Method 17 Configuration

\begin{tabular}{ll}
\hline Component & \multicolumn{1}{c}{ Details } \\
\hline Nozzle & Quartz \\
Filter & Quartz, in glass \\
Probe & Quartz heated to a minimum temperature of 120EC \\
Connector Line & Teflon line used to connect from probe to impingers. Heated to a minimum of \\
& 120EC \\
Impingers 1 and 2 & $1 \mathrm{~N} \mathrm{KCl} \mathrm{solution;} \mathrm{modified} \mathrm{Smith} \mathrm{Greenburg} \mathrm{(SG)} \mathrm{impinger}$ \\
Impinger 3 & $1 \mathrm{~N} \mathrm{KCl} \mathrm{solution;} \mathrm{standard} \mathrm{SG} \mathrm{impinger}$ \\
Impinger 4 & $5 \%$ nitric acid-10\% hydrogen peroxide; modified SG impinger \\
Impingers 5 and 6 & $10 \%$ sulfuric acid-4\% potassium permanganate; modified SG impinger \\
Impinger 7 & $10 \%$ sulfuric acid-4\% potassium permanganate; standard SG impinger \\
Impinger 8 & Silica gel; modified SG impinger \\
\hline
\end{tabular}

- Container 5 - Impingers 5 through $7\left(\mathrm{H}_{2} \mathrm{SO}_{4}-\mathrm{KMnO}_{4}\right.$ impingers $)$ and rinse

- Silica Gel - Impinger 8 (silica gel impinger). Note that this sample is weighed for moisture determination and is not included in the mercury analysis.

The sample fractions were prepared for analyses as specified in the method. It should be noted that these preparation steps are the most difficult aspect of the $\mathrm{OH}$ method and the most likely source of error. This is discussed in more detail in Section 5, Quality Assurance/Quality Control.

After each fraction had been prepared, mercury analysis was accomplished by CVAA. CVAA is a method based on the absorption of radiation at $253.7 \mathrm{~nm}$ by mercury vapor. The mercury is reduced to the elemental state and aerated from solution in a closed system. The mercury vapor passes through a cell positioned in the light path of an atomic absorption spectrometer. Mercury concentration is proportional to the resulting absorbance. A soda-lime trap and a magnesium perchlorate trap were used to precondition the gas before it entered the absorption cell. For all the $\mathrm{OH}$ mercury samples (except the filter), the analyses were done on-site.

\subsection{Multicyclone Setup}

The multicyclone setup consisted of a five-stage Teflon-coated stainless steel multicyclone followed by a backup filter. The probe, transfer lines, and impinger train were identical to the standard $\mathrm{OH}$ method setup. The operation of the sampling was not isokinetic, but rather at a constant flow rate 
necessary for the proper fractionation of size within the cyclones. In addition, to minimize disturbance of the multicyclone during sampling and to obtain samples simultaneously with the standard $\mathrm{OH}$ method, as well as limitations because of the size of the multicyclone setup, a single traverse point was used.

\subsection{EPA Method 26A}

To measure concentration of chlorides in the flue gas, EPA Method 26A was used. A schematic of the train is shown in Figure 6. This method was designed to measure both the $\mathrm{HCl}$ and $\mathrm{Cl}_{2}$ concentrations in the flue gas. During the sampling, the separation of the halides $(\mathrm{HCl})$ from the halogens $\left(\mathrm{Cl}_{2}\right)$ is accomplished physically within the impinger matrices. $\mathrm{Cl}_{2}$ exhibits a low solubility in acid solutions $\left(0.1 \mathrm{~N} \mathrm{H}_{2} \mathrm{SO}_{4}\right)$, but is collected effectively in basic solutions $(0.1 \mathrm{~N} \mathrm{NaOH})$. The $\mathrm{HCl}$, on the other hand, is captured effectively by the $0.1 \mathrm{~N} \mathrm{H}_{2} \mathrm{SO}_{4}$ solution. The impinger train is operated similarly to other sampling procedures such as EPA Method 5 or EPA Method 29. During the testing, M26A was not used for particulate matter. Since the gas-phase chlorides are not impacted by gas flow or isokinetic sampling rate, the sampling was operated at a constant flow from a single traverse point. It has been found that in the presence of $\mathrm{SO}_{2}$, the method does not accurately speciate chlorides (6); however, the method still gives an accurate measurement of total chlorides. Once the chlorides were collected in the solutions, they were analyzed using ion chromatography techniques.

\subsection{Determination of Coal and Ash Mercury}

Mercury in coal was determined using two different methods. The first method was to digest the coal with $\mathrm{HNO}_{3}$ and $\mathrm{HCl}$ in sealed high-pressure Teflon digestion vessels similar to

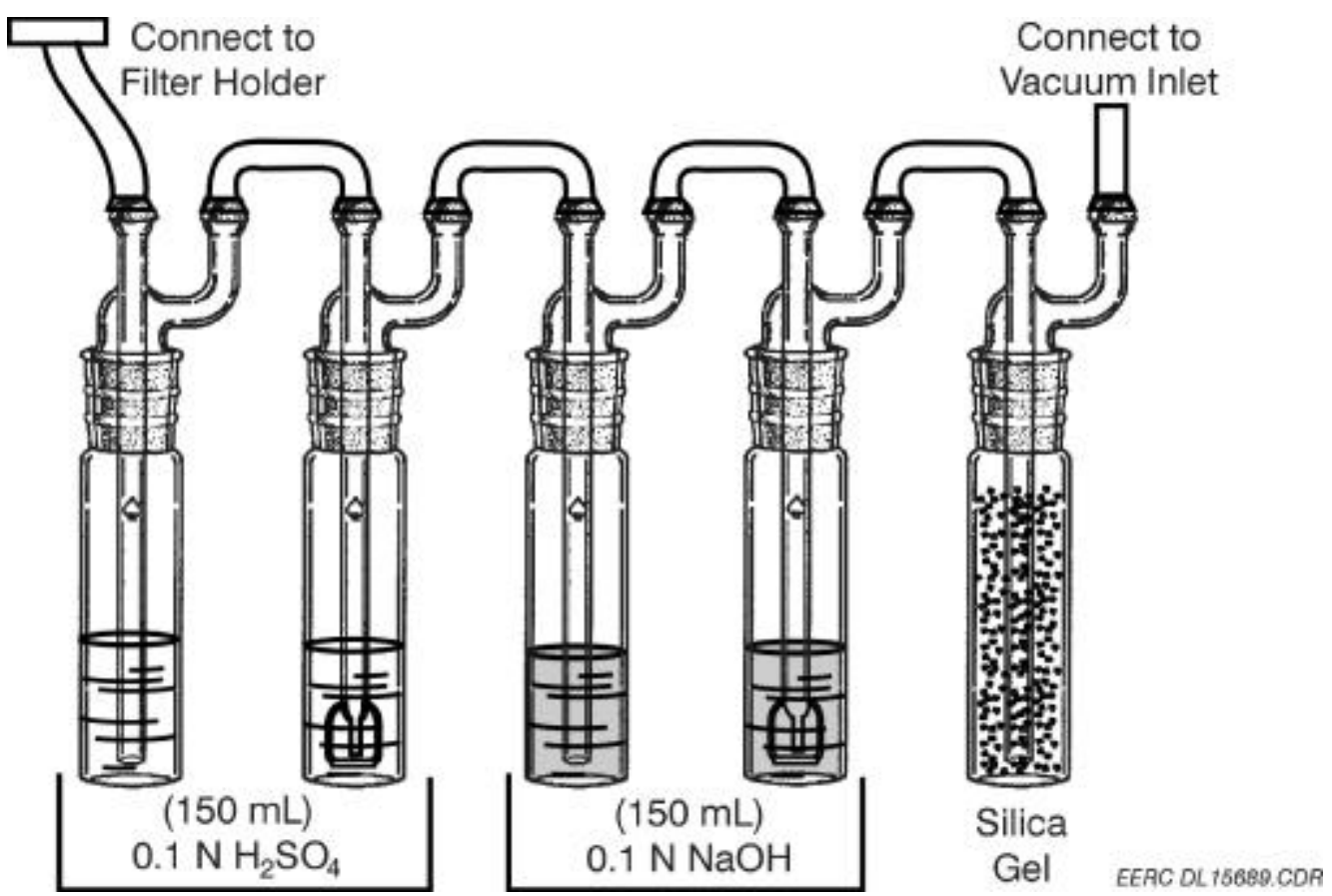

Figure 6. Schematic of EPA Method 26A. 
those used for EPA Method SW846 3051, Microwave Assisted Acid Digestion of Sediments, Sludges, Soils and Oils. The modifications to the method include 1) the use of larger, high-pressure Teflon vessels designed specifically for coal; 2) the use of nitric and hydrochloric acid for digestion; and 3) the use of multiple cooldown and venting steps to completely digest the coal. The digested samples were analyzed by CVAA according to EPA Method 7471A. All values were reported as $\mu \mathrm{g} / \mathrm{g} \mathrm{Hg}$ on a dry-coal basis. The second method used the Milestone DMA- 80 instrument. In this method, the coal is heated to drive off the mercury. The mercury is then adsorbed on a gold trap and desorbed into a CVAA. This method is also approved by EPA as Method 7473. The Milestone DMA-80 automates the process.

Mercury in the baghouse hopper ash and filter samples was also determined using EPA method 7473 and a modification of EPA Method SW846 3051. The modifications include the use $\mathrm{HF}, \mathrm{HNO}_{3}$, $\mathrm{HCl}$, and boric acid and a tenfold reduction in the volumes of reagents and sample used to reduce waste. This reduction in reagent volume is acceptable, because modern dedicated mercury analyzers do not require the large volumes that previous manual methods required. The digested samples were analyzed by CVAA according to EPA Method 7471A. All values were reported as $\mu \mathrm{g} / \mathrm{g}$ of mercury.

\subsection{Auxiliary Flue Gas Measurements}

EPA methods for auxiliary flue gas measurements included flue gas flow rate using EPA Methods 1 and 2 (pitot traverse). To determine the $\mathrm{O}_{2}$ levels at each sample location, a portable Teledyn $\mathrm{O}_{2}$ analyzer using a paramagentic cell was used. This portable $\mathrm{O}_{2}$ analyzer's linearity was verified using EPA Protocol 1 certified gas standards. In addition, the plant had $\mathrm{O}_{2}$ CEMs that gave the $\mathrm{O}_{2}$ and $\mathrm{CO}_{2}$ concentration at the outlet of the boiler. Therefore, any leaks into the ducts at each of the sample points could be determined. For the purposes of this report, the mercury concentrations are reported on a constant $-\mathrm{O}_{2}$ basis $\left(3 \% \mathrm{O}_{2}\right)$. The flue gas moisture was measured using EPA Method 4 (condensation/gravimetric analysis). All these measurements were collected as integral parts of the mercury speciation test runs at all sampling locations.

\subsection{Mercury CEMs}

Concurrently with the $\mathrm{OH}$ method sampling, a total of four mercury CEMs were used to obtain gas-phase mercury concentration data at the stack. It was originally intended that the CEMs would provide speciation data; however, the mercury concentrations at the stack were so low that the instruments were only used to measure total mercury. The instruments used for these tests were:

- Semtech Hg 2000/2010

- Tekran

- PS Analytical Sir Galahad

A brief description of each these instruments is provided below. The flue gas was converted and conditioned with a separate unit, and the conditioned dry gas was then analyzed using the CEMs.

Semtech Hg 2000 Analyzer. The commercial Semtech Hg 2000 and Hg 2010 mercury analyzers (Semtech Metallurgy AB, Lund, Sweden) are essentially portable Zeeman-modulated CVAA 
instruments that can monitor $\mathrm{Hg}^{0}$ continuously. The analyzer uses Zeeman effect background correction by applying a modulated magnetic field to a mercury lamp to minimize interferences from the presence of $\mathrm{SO}_{2}$, hydrocarbons, and fine particulate in the flue gas sample. The operating range of the analyzer is 0.3 $\mu \mathrm{g} / \mathrm{Nm}^{3}$ to $20 \mathrm{mg} / \mathrm{Nm}^{3} \mathrm{Hg}^{0}$, as specified by Semtech Metallurgy AB. The Semtech $\mathrm{Hg} 2000$ has also been certified by TUEV Rheinland for determining compliance with the German legal limit of $50 \mu \mathrm{g} / \mathrm{Nm}^{3}$ for total mercury from waste incinerators. The only difference between the $\mathrm{Hg} 2000$ and 2010 is that the 2010 was designed to improve the noise-to-signal ratio.

PS Analytical Sir Galahad and Teckran. These two mercury CEMs operate using the same technique. The analyzers are based on the principle of atomic fluorescence, which provides an inherently more sensitive signal than atomic absorption. The systems use a gold-impregnated silica support for preconcentrating the mercury and separating it from potential interferences that degrade sensitivity. The Sir Galahad analyzer was initially used to monitor total mercury continuously in the urban environment and in natural gas. The Tekran was developed to measure atmospheric mercury. However both of these instruments (with the proper pretreatment) can be used in a variety of gaseous media, including combustion flue gas

There is a four-step process to obtain a flue gas mercury measurement using these instruments. In the first step, flue gas is pumped through a gold trap that is maintained at a constant temperature. Before the mercury is desorbed from the gold trap, a flushing step is initiated to remove any flue gas that may be present, because it has a damping effect on the mercury fluorescence. When this is completed, the analysis step begins. The heating coil is activated, and the gold trap is heated to approximately 500EC. This desorbs the mercury from the trap, and the mercury is carried into the fluorescence detector. The gold trap is rapidly cooled by pumping argon over it, in preparation for the next sample. The total time for the process is 3 to 5 minutes.

Both instruments are calibrated using $\mathrm{Hg}^{0}$ as the primary standard. $\mathrm{The}^{\mathrm{H}} \mathrm{g}^{0}$ is contained in a closed vial that is held in a thermostatic bath. The temperature of the mercury is monitored, and the amount of mercury is calculated using vapor pressure calculations. Typically, the calibration of these instruments have proven stable over a 24 -hr period.

\subsection{MERCURY MEASUREMENT RESULTS}

\subsection{Coal Mercury}

The mercury analyses (using both methods) from the coals collected during sampling are shown in Table 9. From the data, it appears that the Milestone instrument gave results comparable to those obtained using the more traditional microwave digestion method. The coal mercury concentrations in the collected samples are significantly lower than those reported for the ICR. For Quarters 1 and 3 (no second-quarter data were reported), the mercury in the coal burned at the Valmont Station was reported to be $37 \mathrm{ppb} \pm 16.4 \mathrm{ppb}$ for 14 coal samples. As Table 9 shows, this is about 3 times higher than the measured coal mercury in the samples collected during testing. There is no explanation for this; 
however, the flue gas sampling was completed during the second- quarter ICR coal reporting period when no coal mercury concentrations were reported. Perhaps during this time the mercury in the coal was lower. Although the average coal mercury concentration reported for the ICR was higher, there were several coal samples that had mercury concentrations similar to those collected during the flue gas testing. As discussed later in this report, the lower mercury concentration in the coal is supported by the mercury balances and the mercury CEM data.

\section{TABLE 9}

Mercury in the Coal from the Valmont Station

\begin{tabular}{lcc}
\hline Run & $\begin{array}{c}\text { Coal Mercury } \\
\text { Concentrations } \\
\text { (digestion), } \\
\text { ppb }\end{array}$ & $\begin{array}{c}\text { Coal Mercury } \\
\text { Concentrations } \\
\text { (milestone), } \\
\text { ppb }\end{array}$ \\
\hline 1 & 10.0 & 14.3 \\
2 & 5.5 & 5.5 \\
3 & 8.3 & 8.1 \\
Average & $7.9 \pm 2.3$ & $9.3 \pm 5.2$ \\
\hline
\end{tabular}

\subsection{Baghouse Hopper Ash, Sample Filter, and Multicyclone}

As expected on the basis of previous mercury sampling at this plant, the mercury collected on the filters of the baghouse inlet sample trains and on the ash collected from the baghouse hoppers (particulate-bound mercury) was a high percentage of the total mercury, about $80 \%$. Comparing the mercury concentration on the filter ash collected at the baghouse inlet and the mercury concentration in the baghouse hopper ash (Table 10) shows they are essentially the same.

The mercury was also measured on the filters at the outlet of the baghouse. Because of the high particulate collection efficiency of the baghouse, the concentration of particulate-bound mercury measured at the outlet of the baghouse was below detection limits $\left(<0.002 \mu \mathrm{g} / \mathrm{Nm}^{3}\right)$. Therefore, $>80 \%$ of the mercury was removed by the baghouse.

A five-stage Teflon-coated multicyclone was used to determine the particle-size distribution at the inlet to the baghouse. As can be seen from Figure 7, a very high percentage of the mass at the inlet to the baghouse was $>10 \mu \mathrm{m}$, approximately $75 \%$ mass. Extrapolating the data from Figure 7 , the $\mathrm{D}_{50}$ at this location is about $13 \mu \mathrm{m}$.

TABLE 10 
Comparison of Mercury Concentration in ESP Ash and Sample Filters

\begin{tabular}{lcc}
\hline Run & $\begin{array}{c}\text { Baghouse Hopper Ash, } \\
\boldsymbol{\mu g} / \mathbf{g}\end{array}$ & $\begin{array}{c}\text { OH Sample Filter, } \\
\boldsymbol{\mu g} / \mathbf{g}\end{array}$ \\
\hline 1 & 0.132 & 0.138 \\
2 & 0.0714 & 0.165 \\
3 & 0.115 & 0.175 \\
Average & 0.115 & 0.159 \\
\hline
\end{tabular}

The mercury concentration in each catch of the multicyclone and on the filter is plotted as a function of the cut points of the cyclones, shown in Figure 8. It appears the mercury preferentially sorbs on the fine particles. This was also true when multicyclone samples were taken at Great River Energy's Stanton Station (7). This indicates that surface adsorption may be an important mechanism resulting in the association of mercury with the ash material. To further illustrate the preferential sorption, the concentration of mercury in each of the multicyclone stages and the backup filter are shown in Table 11. The combined total of particulate-bound mercury measured using the multicyclone setup (shown in Table 11) matches reasonably well with the $\mathrm{OH}$ filter data (shown in Table 10).

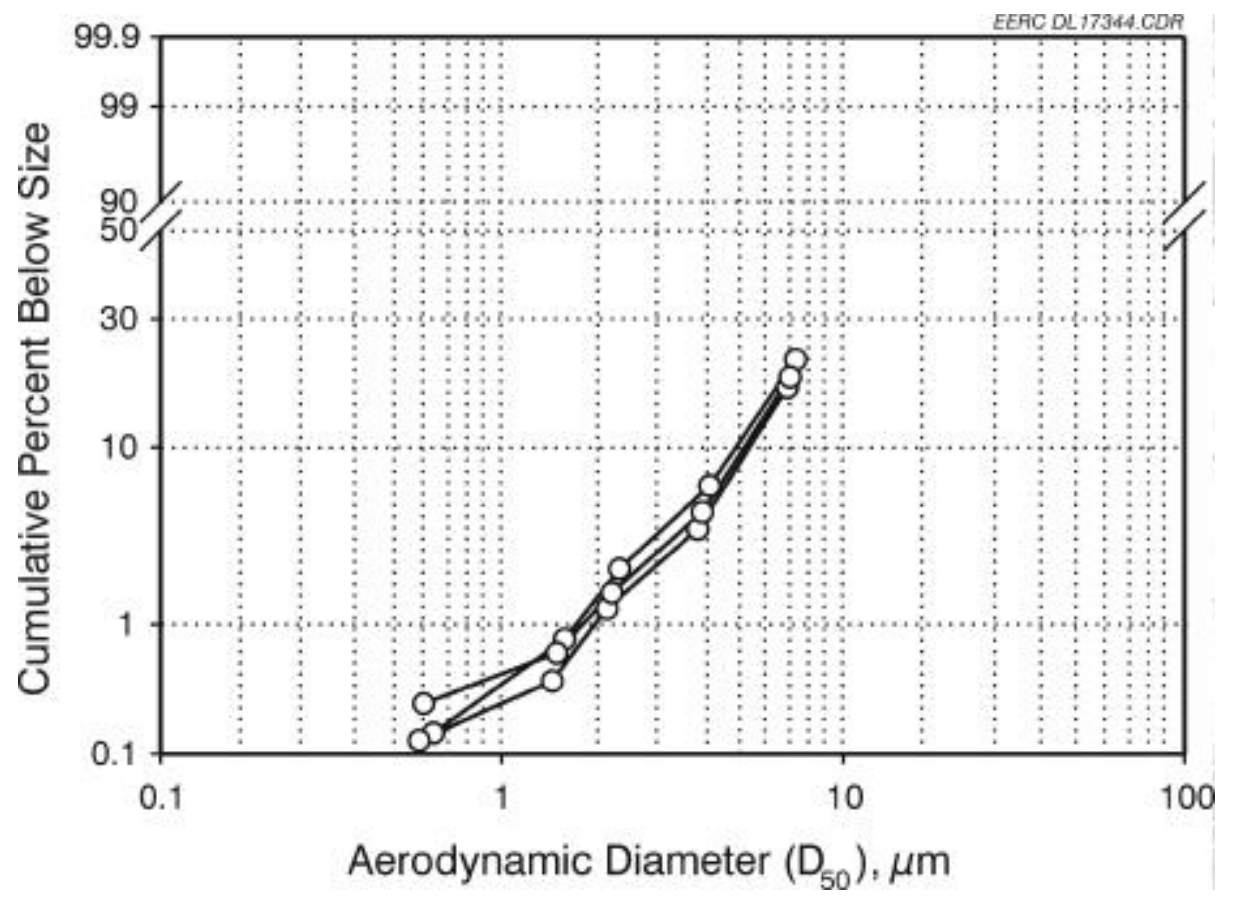

Figure 7. Particle-size distribution at the inlet to baghouse. 


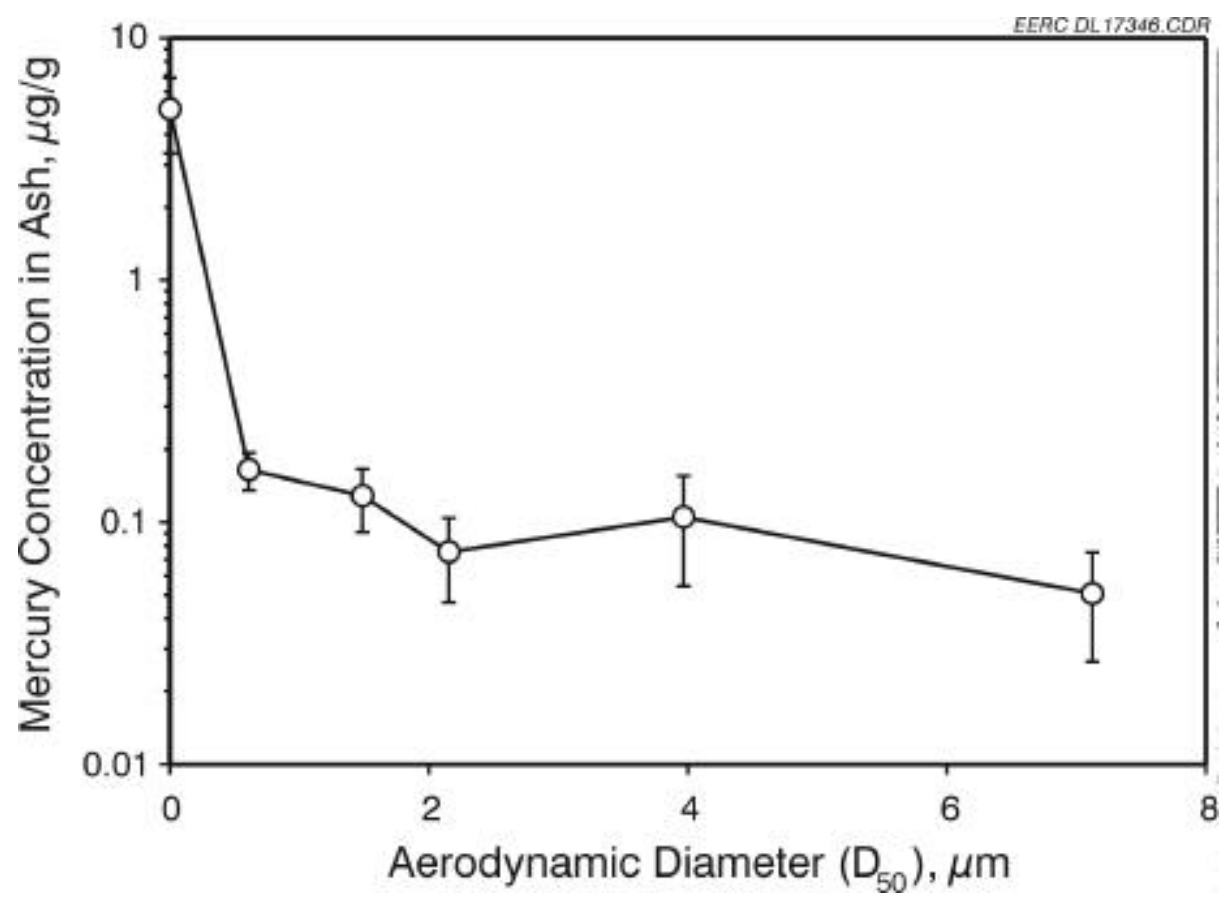

Figure 8. Effect of particle size on the concentration of particulate-bound mercury.

TABLE 11

Mercury Concentration in Multicyclone Stages and Backup Filter

Mercury Concentration, $\mathbf{F g} / \mathrm{g}$

\begin{tabular}{|c|c|c|c|c|c|c|c|}
\hline RunlStage & Filter & 5 & 4 & 3 & 2 & 1 & $\begin{array}{c}\text { Combined } \\
\text { Total }^{1} \\
\end{array}$ \\
\hline 1 & 5.284 & 0.148 & 0.0860 & 0.0450 & 0.0679 & 0.0379 & 0.0522 \\
\hline 2 & 6.721 & 0.198 & 0.142 & 0.0788 & 0.162 & 0.0356 & 0.0644 \\
\hline 3 & 3.247 & 0.147 & 0.157 & 0.102 & 0.0843 & 0.0786 & 0.0895 \\
\hline Average & 5.084 & 0.164 & 0.128 & 0.0726 & 0.105 & 0.0507 & 0.0687 \\
\hline
\end{tabular}

${ }^{1}$ Calculated by summing the total mercury in the ash and dividing by the total ash collected.

\subsection{Flue Gas Mercury Speciation Results}

This section presents the flue gas mercury speciation results, which are shown in Table 12. All data are based on $68 \mathrm{EF}$, dry conditions and are adjusted to $3 \%$ oxygen. All the mercury data were averaged, and a standard deviation calculated. As can be seen, the mercury concentrations were very low. This agrees with the very low mercury concentration measured in the coal. 
TABLE 12

Mercury Speciation Results for Unit V5 Valmont Station

\section{Baghouse Inlet}

Stack

Particulate-

Total Particulate-

$\mathrm{Hg}, \quad$ Bound $\mathrm{Hg}, \quad \mathrm{Hg}^{0}, \quad \mathbf{H g}^{2+}$, $\mu \mathrm{g} / \mathrm{Nm}^{3} \quad \mu \mathrm{g} / \mathrm{Nm}^{3} \quad \mu \mathrm{g} / \mathrm{Nm}^{3} \quad \mu \mathrm{g} / \mathrm{Nm}^{3}$

\begin{tabular}{lcccc|rrrr} 
& $\boldsymbol{\mu g} / \mathbf{N m}^{3}$ & $\boldsymbol{\mu g} / \mathbf{N m}^{3}$ & $\boldsymbol{\mu g} / \mathbf{N m}^{3}$ & $\boldsymbol{\mu g} / \mathbf{N m}^{3}$ & $\boldsymbol{\mu g} / \mathbf{N m}^{3}$ & $\boldsymbol{\mu g} / \mathbf{N m}^{3}$ & $\boldsymbol{\mu g}_{\mathbf{N}} \mathbf{N m}^{3}$ & $\boldsymbol{\mu g} / \mathbf{N m}^{\mathbf{3}}$ \\
\hline & 1.21 & 0.92 & 0.18 & 0.11 & 0.15 & $<0.002$ & 0.03 & 0.12 \\
& 1.12 & 0.92 & 0.13 & 0.07 & 0.11 & $<0.002$ & 0.02 & 0.09 \\
& 1.51 & 1.22 & 0.17 & 0.11 & 0.24 & $<0.002$ & 0.04 & 0.20 \\
Average & 1.28 & 1.02 & 0.16 & 0.10 & 0.17 & $<0.002$ & 0.02 & 0.12 \\
Std. Dev. & 0.20 & 0.18 & 0.03 & 0.03 & 0.07 & ---- & 0.01 & 0.06 \\
\hline
\end{tabular}

Figure 9 shows the mercury removal across the baghouse. It is clearly evident that the baghouse effectively removes particulate-bound mercury and $\mathrm{Hg}^{0}$ As stated earlier and shown in Table 12, almost all the mercury at the baghouse inlet is in the form of particulate-bound mercury. The small amount of gaseous mercury $\left(0.26 \mu \mathrm{g} / \mathrm{Nm}^{3}\right)$ is about $60 \% \mathrm{Hg}^{0}$ and $40 \% \mathrm{Hg}^{2+}$. On the basis of the mercury concentration in the flue gas at the stack, the baghouse removes, as expected, all the particulate-bound mercury, but also removes $>85 \%$ of the $\mathrm{Hg}^{0}$. The baghouse does not appear to remove any of the $\mathrm{Hg}^{2+}$. Overall, the baghouse removed $94.5 \%$ of the mercury measured

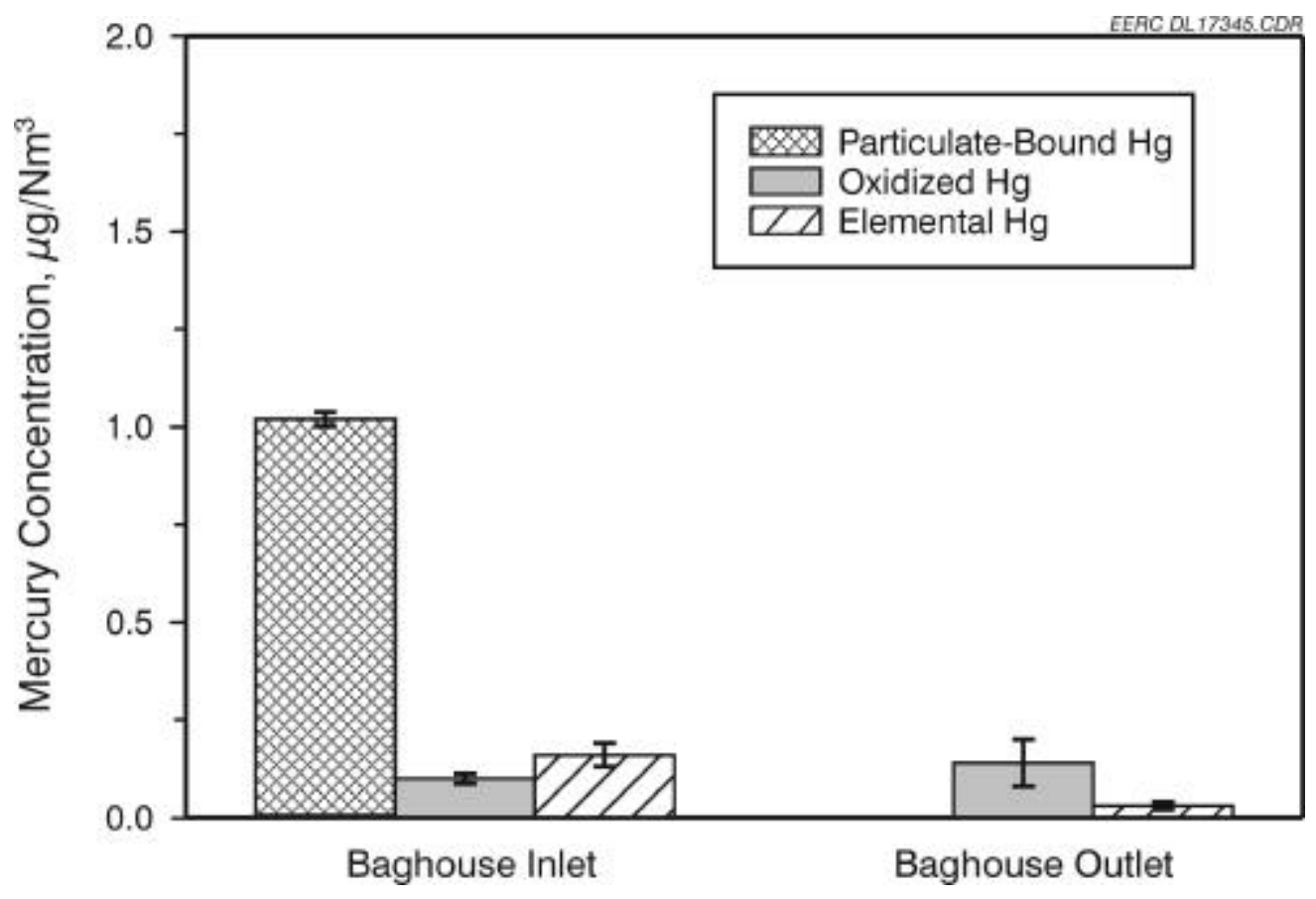

Figure 9. Effect of the baghouse on speciated mercury concentration. 
TABLE 13

Average Partitioning of Flue Gas Mercury Species in Unit 10

\begin{tabular}{lccc}
\hline Hg Species & $\begin{array}{c}\text { Air } \\
\text { Preheater, \% }\end{array}$ & $\begin{array}{c}\text { Inlet to Baghouse, } \\
\mathbf{\%}\end{array}$ & $\begin{array}{c}\text { Stack, } \\
\text { \% }\end{array}$ \\
\hline Particulate-Bound & $<0.1$ & 79.7 & 1.3 \\
$\mathrm{Hg}^{2+}$ & 1.8 & 7.5 & 83.2 \\
$\mathrm{Hg}^{0}$ & 99.4 & 12.8 & 16.8 \\
\hline
\end{tabular}

at the inlet. Table 13 presents the mercury speciation partitioning at each of the sample locations. These results indicate that this plant should be able to meet almost any mercury regulation that may be proposed for coal-fired utilities without any changes to the system. In fact, if they install a spray dryer for $\mathrm{SO}_{2}$ control as is being planned, this plant may be as close to zero mercury emissions as possible.

Mercury speciation sampling was also done at the air preheater inlet to determine the impact of temperature on the concentration of particulate-bound and speciated mercury. These results are shown in Table 14. As can be seen from Table 14, at $750 \mathrm{EF}$ all the mercury is $\mathrm{Hg}^{0}$. Therefore almost all the mercury interactions with other flue gas components occurs downstream of the air preheater.

TABLE 14

Mercury Speciation Results at the Inlet to the Air Preheater

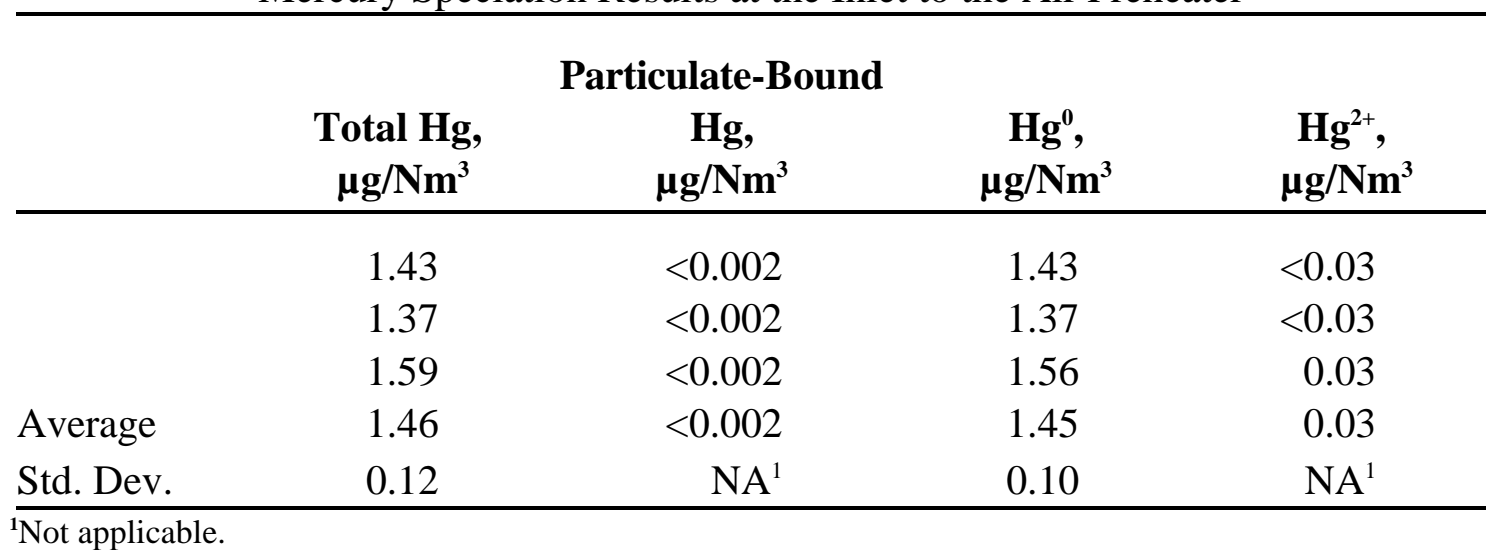

The data obtained from the $\mathrm{OH}$ method modified with the multicyclone setup was used to examine the effect of the filter on mercury speciation. Sampling with the multicyclone setup does not result in the sample passing through a significant filter cake during the particulate separation process. Although the 
multicyclone setup contains a backup filter, the amount of material trapped is very small, and thus the filter cake is minimal. Bench-scale experiments have shown that some fly ashes can trap mercury and/or convert mercury species when contact between mercury-laden flue gas and the ash takes place while flue gas passes through a filter cake of the ash $(5,8)$. The mercury speciation results of the multicyclone sampling setup are compared to the $\mathrm{OH}$ method results in Table 15.

\section{TABLE 15}

Comparison of Mercury Speciation Results, Multicyclone versus Filter

\begin{tabular}{|c|c|c|c|c|c|c|c|c|}
\hline Run & $\begin{array}{c}\text { Total Hg, } \\
\mu \mathrm{g} / \mathrm{Nm}^{3}\end{array}$ & $\begin{array}{c}\text { ghouse Inlet } \\
\text { Particulate- } \\
\text { Bound Hg, } \\
\mu \mathrm{g} / \mathrm{Nm}^{3}\end{array}$ & $\begin{array}{c}\mathrm{Hg}^{0} \\
\mu \mathrm{g} / \mathrm{Nm}^{3}\end{array}$ & $\begin{array}{c}\mathbf{H g}^{2+} \\
\mu \mathrm{g} / \mathrm{Nm}^{3}\end{array}$ & $\begin{array}{c}\text { Total Hg, } \\
\mu \mathrm{g} / \mathrm{Nm}^{3}\end{array}$ & $\begin{array}{c}\text { house Inlet } \\
\text { Particulate- } \\
\text { Bound } \mathrm{Hg} \text {, } \\
\mu \mathrm{g} / \mathrm{Nm}^{3}\end{array}$ & $\begin{array}{c}\mathrm{Hg}^{0} \\
\mu \mathrm{g} / \mathrm{Nm}^{3}\end{array}$ & $\begin{array}{c}\mathrm{Hg}^{2+} \\
\mu \mathrm{g} / \mathrm{Nm}^{2}\end{array}$ \\
\hline 1 & 1.21 & 0.92 & 0.18 & 0.11 & 1.98 & 0.32 & 1.03 & 0.63 \\
\hline 2 & 1.12 & 0.92 & 0.13 & 0.07 & 0.74 & $\mathrm{NA}^{1}$ & 0.57 & 0.17 \\
\hline 3 & 1.51 & 1.22 & 0.17 & 0.11 & 1.28 & 0.52 & 0.60 & 0.16 \\
\hline Average & 1.28 & 1.02 & 0.16 & 0.10 & 1.33 & 0.42 & 0.73 & 0.32 \\
\hline Std. Dev. & 0.20 & 0.18 & 0.03 & 0.03 & 0.62 & 0.14 & 0.25 & 0.27 \\
\hline
\end{tabular}

The data in Table 15 show that when you have an ash that has a high affinity for mercury, a cyclone-type particulate collector may be a better choice than a filter for doing $\mathrm{OH}$ sampling. It appears to better represent the type of contact between the fly ash and mercury that occurs in the duct, thereby giving a more accurate representation of the actual inlet mercury speciation.

The multicyclone data also support the conclusion that the baghouse, in addition to removing the particulate-bound mercury, removed a high percentage of the $\mathrm{Hg}^{0}$. When a filter (same effect as the baghouse) is used prior to the $\mathrm{OH}$ sampling train, the measured $\mathrm{Hg}^{0}$ mercury concentration is considerably less than the $\mathrm{Hg}^{0}$ concentration measured using the multicyclone (less particulate-bound mercury and more $\mathrm{Hg}^{0}$. It should also be noted that for these tests, the multicyclone was Teflon-coated and there was no conversion of $\mathrm{Hg}^{0}$ to $\mathrm{Hg}^{2+}$, as was the case at Stanton Station (7).

Because it is thought the level of chlorides in the flue gas stream may influence mercury speciation, two EPA Method 26A sample trains were completed at the inlet to the spray dryer. This sample method was designed to measure both the $\mathrm{HCl}$ concentration in the gas stream and the $\mathrm{Cl}_{2}$. In practice, the method does not work very well as a chloride speciation measurement method, but does provide a good measurement of the total chloride concentration in the flue gas. The EPA Method 26A results are shown 
in Table 16. As shown, the chloride concentration is very low. This is typical of all western fuels (both lignites and subbituminous). For these fuels, the

TABLE 16

Chloride Concentrations in the Flue Gas

\begin{tabular}{lccc}
\hline Sample & $\begin{array}{c}\text { HCl } \\
\text { Concentration, } \\
\mathbf{p p m}\end{array}$ & $\begin{array}{c}\mathbf{C l}_{2} \\
\text { Concentration, } \\
\mathbf{p p m}\end{array}$ & $\begin{array}{c}\text { Total Chlorides } \\
\mathbf{a s} \mathbf{C l}, \\
\mathbf{p p m}\end{array}$ \\
\hline 1 & $<0.4$ & 0.5 & 1.0 \\
2 & $<0.4$ & 0.4 & 0.7 \\
\hline
\end{tabular}

chloride concentration is usually $<15 \mathrm{ppm}$. Although the chloride concentration in the flue gas is low, it is still several orders of magnitude higher than the mercury concentration. But still, this does bring up the question of whether the actual $\mathrm{Hg}^{2+}$ compound being measured is $\mathrm{HgCl}_{2}$ as thought.

\subsection{Mercury CEM Results}

Concurrently with the ICR sampling, a total of four mercury CEMs were also used to obtain gasphase mercury concentration data at the stack location. The instruments used included two Semtech analyzers, a PS Analytical instrument, and a Tekran instrument. A comparison of the gas-phase mercury concentrations using mercury CEMs and the $\mathrm{OH}$ method (not corrected to $3 \% \mathrm{O}_{2}$ ) are provided in Figures 10 and 11 . The data obtained with these instruments verify the low concentrations of mercury obtained with the $\mathrm{OH}$ method and measured in the coal. The two Semtech analyzers were not very useful for these tests. Because of the low mercury concentrations, the noise-to-signal ratio was too large. Both the PS Analytical Sir Galahad and the Tekran instruments are inherently more sensitive (because they are fluorescence-based instruments as opposed to absorbance-based), and the mercury concentrations measured with these instruments match the $\mathrm{OH}$ results very well. It should be noted that during the first day of testing, the PS Analytical instrument was not used, as it was being moved. However, on the next day, when both instruments were used, the results for the two were nearly identical. It was planned that the instruments would provide mercury speciation information at the stack. However, the extraordinarily low mercury concentration made this impractical.

\subsection{Emission Factors}

The emission factors at the stack for Unit V5 at the Valmont Station are shown in Table 17. The emission factors for total mercury averaged only $0.15 \mathrm{lb} / 10^{12} \mathrm{Btu}$, with a standard deviation of 0.07

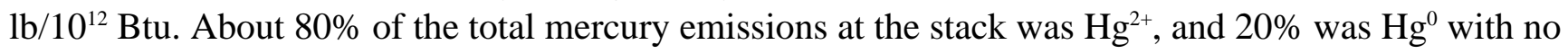
particulate-bound mercury. 


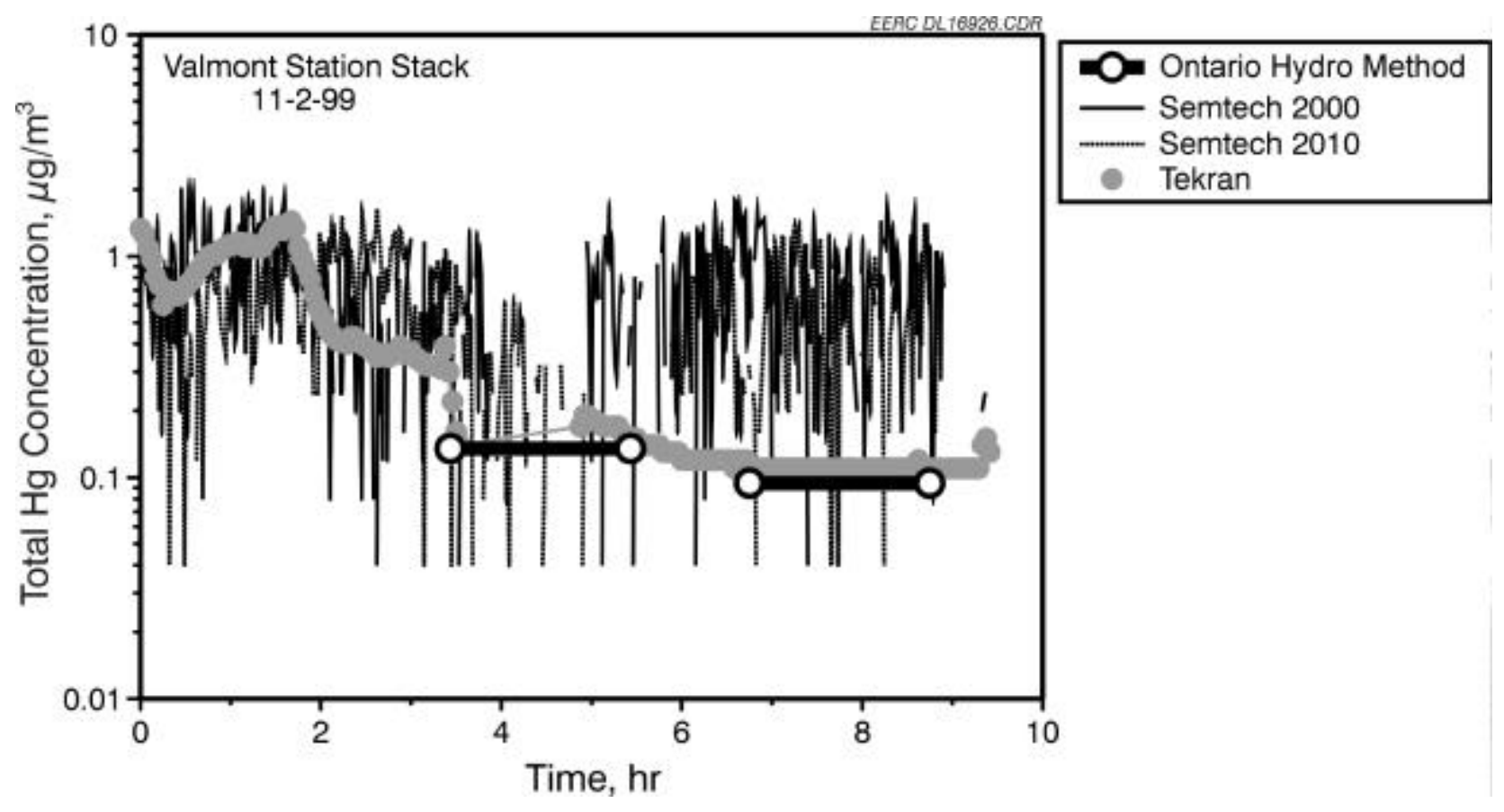

Figure 10. Mercury CEM data, Day 1.

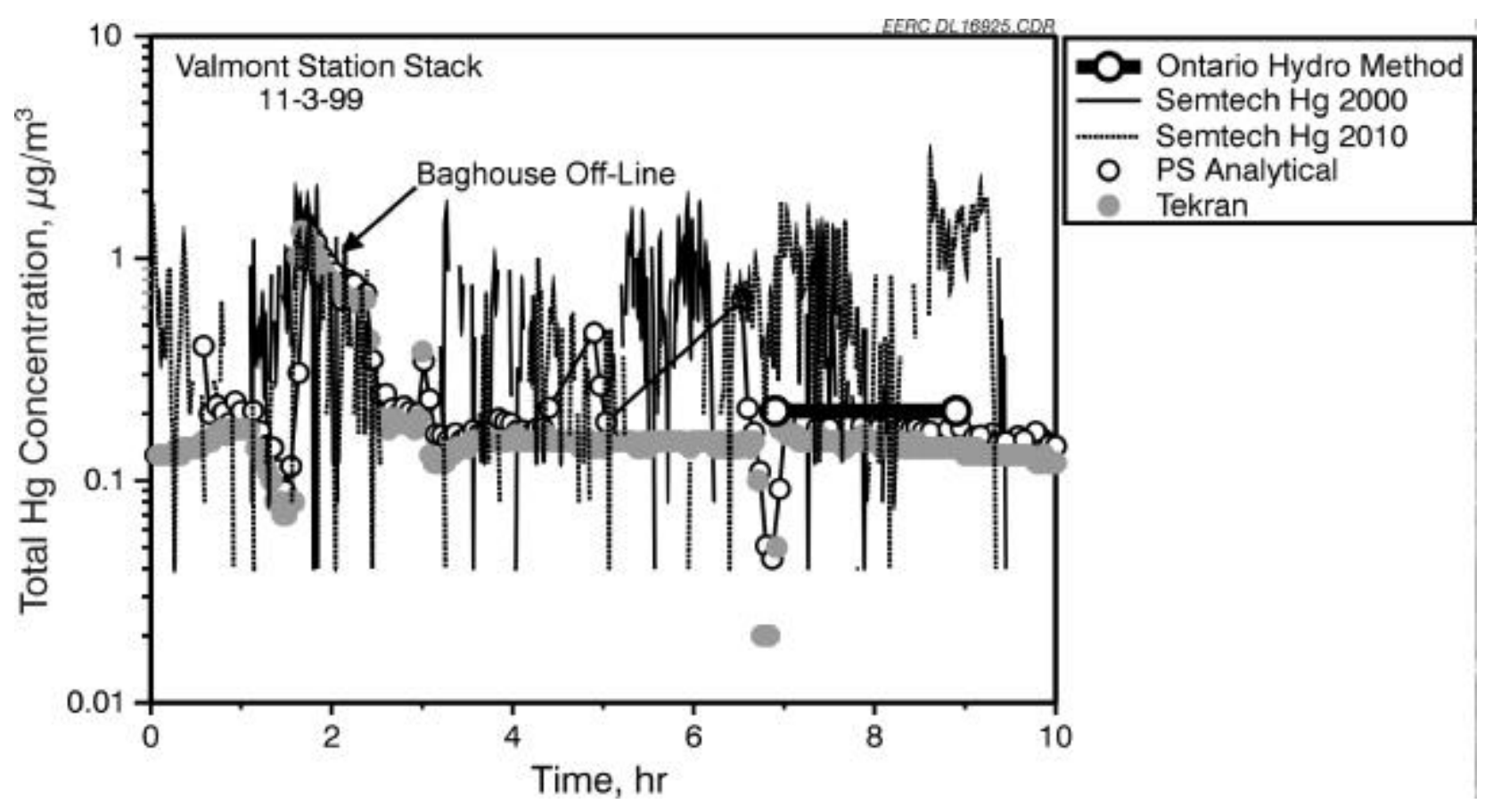

Figure 11. Mercury CEM data, Day 2. 
TABLE 17

Emission Factors for Mercury at the Stack

\begin{tabular}{|c|c|c|c|c|c|c|c|}
\hline \multirow[b]{2}{*}{ Run } & \multirow[b]{2}{*}{$\begin{array}{c}\text { Coal Feed } \\
\text { Rate, } \\
\text { Klb/hr }\end{array}$} & \multirow[b]{2}{*}{$\begin{array}{c}\text { Coal Heating } \\
\text { Value, } \\
\text { Btu/lb }\end{array}$} & \multirow[b]{2}{*}{$\begin{array}{c}\text { Stack Gas } \\
\text { Flow Rate, } \\
\text { Kscfm }\end{array}$} & \multicolumn{4}{|c|}{ Emission Factors, $\mathbf{l b} / \mathbf{1 0}^{12}$ Btu } \\
\hline & & & & $\begin{array}{l}\text { Particulate- } \\
\text { Bound Hg }\end{array}$ & $\mathbf{H g}^{2+}$ & $\mathbf{H g}^{0}$ & Total Hg \\
\hline 1 & 156 & 10317 & 423 & $<0.002$ & 0.10 & 0.03 & 0.12 \\
\hline 2 & 155 & 10250 & 458 & $<0.002$ & 0.08 & 0.02 & 0.09 \\
\hline 3 & 202 & 10258 & 449 & $<0.002$ & 0.19 & 0.04 & 0.22 \\
\hline Average & 150 & 6745 & 443 & $<0.002$ & 0.12 & 0.03 & 0.15 \\
\hline Std. Dev & --- & --- & --- & $\mathrm{NA}^{1}$ & 0.06 & 0.01 & 0.07 \\
\hline
\end{tabular}

${ }^{1}$ Not applicable.

The emission factors shown in Table 17 were calculated using the coal feed rate, coal heating value, and flow rates (plant data). However, emission factors are generally calculated using the $F_{d}$ values as specified for EPA Method 19. A comparison between the two methods of calculating emission factors is shown in Table 18. As can be seen from the data, the methods gave similar results, indicating that coal feed and gas flow rates obtained by the plant are accurate.

TABLE 18

Mercury Emission Factors at the Stack, Comparison of Calculation Methods Emission Factors, $\mathrm{lb} / 10^{12}$ Btu

\begin{tabular}{|c|c|c|c|c|c|c|c|c|}
\hline \multirow[b]{3}{*}{ Run } & \multicolumn{8}{|c|}{ Emission Factors, $\mathbf{l b} / 10^{12}$ Btu } \\
\hline & \multicolumn{2}{|c|}{ Particulate-Bound $\mathrm{Hg}$} & \multicolumn{2}{|c|}{$\mathbf{H g}^{2+}$} & \multicolumn{2}{|c|}{$\mathrm{Hg}^{0}$} & \multicolumn{2}{|c|}{ Total Hg } \\
\hline & $\begin{array}{l}\text { Plant } \\
\text { Data }\end{array}$ & $\begin{array}{c}\text { Method } \\
19 \\
\end{array}$ & $\begin{array}{l}\text { Plant } \\
\text { Data }\end{array}$ & $\begin{array}{c}\text { Method } \\
19 \\
\end{array}$ & $\begin{array}{l}\text { Plant } \\
\text { Data }\end{array}$ & $\begin{array}{c}\text { Method } \\
19 \\
\end{array}$ & $\begin{array}{l}\text { Plant } \\
\text { Data }\end{array}$ & $\begin{array}{c}\text { Method } \\
19 \\
\end{array}$ \\
\hline 1 & $<0.002$ & $<0.002$ & 0.10 & 0.08 & 0.03 & 0.02 & 0.12 & 0.11 \\
\hline 2 & $<0.002$ & $<0.002$ & 0.08 & 0.06 & 0.02 & 0.01 & 0.09 & 0.07 \\
\hline 3 & $<0.002$ & $<0.002$ & 0.19 & 0.15 & 0.04 & 0.03 & 0.22 & 0.18 \\
\hline Average & $<0.002$ & $<0.002$ & 0.12 & 0.10 & 0.03 & 0.02 & 0.15 & 0.12 \\
\hline Std. Dev & $\mathrm{NA}^{1}$ & $\mathrm{NA}^{1}$ & 0.06 & 0.05 & 0.01 & 0.01 & 0.07 & 0.05 \\
\hline
\end{tabular}

${ }^{1}$ Not applicable. 


\subsection{Mercury Balances}

Two mercury balances were calculated at the Valmont Station. The first was the overall unit balance and the second was across the baghouse. Each mercury balance was determined by comparing the rate of mercury entering the boiler to the rate of mercury leaving. To compute the overall mercury balance, the inlet source of mercury was the mercury in the coal. The only other possible source of mercury entering the combustor at this plant was the combustion air. However, the concentration of mercury in the combustion air was several orders of magnitude lower than the flue gas and is insignificant. Sources of mercury exiting the system were the baghouse hopper ash

and the flue gas that went out the stack. To express the data on the same basis, all the mercury balance data are expressed in units of $\mathrm{lb} / \mathrm{hr}$. To calculate the mercury balance across the baghouse, the rate of mercury entering the baghouse was compared to the rate of mercury leaving the baghouse. The only source of mercury entering the baghouse is the mercury in the flue gas. Mercury exits the baghouse both in the flue gas and the hopper ash.

To calculate the rate of mercury leaving with the baghouse hopper ash, the ash removal rate had to first be calculated. The baghouse inlet and outlet dust loading (shown in Table 2) were used along with the flue gas flow rate. The ash removal rate for the baghouse averaged $8352 \mathrm{lb} / \mathrm{hr}$, with a resulting mercury removal rate with the baghouse hopper ash of $0.0017 \mathrm{lb} / \mathrm{hr}$.

Table 19 shows the flow rates for mercury from the coal, baghouse hopper ash, and in the flue gas at both the inlet and outlet (stack) locations. The calculated mercury balances (outlet/inlet) were generally good. However, because the mercury concentrations were so low, there is a lot of variability in the mercury balances. The mercury concentrations are near the lower limit of quantification of the Ontario Hydro mercury speciation method. The mercury balances for this test are shown in Table 20. Examples of the calculations used in this report are shown in Appendix A. Copies of the raw data sheets are found in the Valmont report submitted to EPA to meet the requirements of the ICR.

TABLE 19

Mercury Flow Rates 


\begin{tabular}{lcccc}
\hline & \multicolumn{4}{c}{ Mercury Flow Rate, lb/hr } \\
\cline { 2 - 5 } Run & $\begin{array}{c}\text { Coal } \\
\text { Feed }\end{array}$ & $\begin{array}{c}\text { Baghouse } \\
\text { Inlet }\end{array}$ & $\begin{array}{c}\text { Baghouse } \\
\text { Hopper Ash }\end{array}$ & Stack \\
\hline 1 & 0.0013 & 0.0015 & 0.0011 & 0.0002 \\
2 & 0.0007 & 0.0015 & 0.0005 & 0.0001 \\
3 & 0.0010 & 0.0020 & 0.0013 & 0.0003 \\
Average & 0.0010 & 0.0017 & 0.0010 & 0.0002 \\
\hline
\end{tabular}

TABLE 20

Mercury Balances

\begin{tabular}{lcc}
\hline Run & ${\text { Overall, } \boldsymbol{\%}^{\mathbf{1}}}^{\text {Across the Baghouse, }}$ \\
\hline 1 & 100.0 & 86.7 \\
2 & 85.7 & 40.0 \\
3 & 160.0 & 80.0 \\
Average & 115.2 & 68.9 \\
\hline 'Outlet/inlet. & &
\end{tabular}

\subsection{QUALITY ASSURANCE/QUALITY CONTROL}

An overall QA/QC program in place at the EERC is designed to maintain overall data integrity. However, additional procedures were instituted specifically for this project.

\subsection{Instrument Setup and Calibration}

The instrument used in the field for mercury determination was a Leeman Labs PS200 CVAA. To measure mercury, the instrument was set up for absorption at $253.7 \mathrm{~nm}$ with a carrier gas of nitrogen and $10 \% \mathrm{w} / \mathrm{v}$ stannous chloride in $10 \% \mathrm{v} / \mathrm{v} \mathrm{HCl}$ as the reductant. Each day the drying tube and acetate trap were replaced and the tubing checked. The rinse container was cleaned and filled with fresh solution of $10 \% \mathrm{v} / \mathrm{v} \mathrm{HCl}$. After the pump and lamp were turned on and warmed up for 45 minutes, the aperture was set to the manufacturer's specifications. A four-point calibration curve was then completed using matrix-matched standards. The detector response for a given standard was logged and compared to specifications to ensure the instrument had been properly set up. A quality control 
standard of a known analyte concentration was analyzed immediately after the instrument was standardized in order to verify the calibration. This quality control standard was prepared from a stock different from that used in the calibration standards. It was required that the values obtained read within $5 \%$ of the true value before the instrument was used. After the initial QC standardizations were completed, standards were run every five samples to check the slope of the calibration curve. All samples were run in duplicate, and one in every ten samples was spiked to verify analyte recovery. A QC chart is maintained at the EERC to monitor the long-term precision of the instrument.

Prior to the testing, all gas-sampling equipment was calibrated according to the Quality Assurance Handbook for Air Pollution Measurement Systems: Volume III. Stationary Source Specific Methods. The uncertainty of the individual measurements was determined using the performance test codes in ANSI/ASME PTC 19.1-1985, Part 1, Measurement Uncertainty, as a guideline.

\subsection{Presampling Preparation}

All data sheets, volumetric flasks, and petri dishes used for sample recovery were marked with preprinted labels. The liquid samples were recovered into premarked volumetric flasks and logged, then analyzed on-site. The filter samples were placed in premarked petri dishes and taken back to the EERC, where they were analyzed using mixed acid digestion techniques. The labels contained identifying data, including date, time, run number, sample port location, and the name of the sampler.

\subsection{Glassware and Plasticware Cleaning and Storage}

All glass volumetric flasks and transfer pipets used in the preparation of analytical reagents and calibration standards were designated Class A to meet federal specifications. Prior to being used for the sampling, all glassware was washed with hot, soapy water, then rinsed with deionized water three times, soaked in $10 \% \mathrm{v} / \mathrm{v}$ nitric acid for a minimum of 4 hours, rinsed an additional three times with deionized water, and dried. The glassware was then stored in closed containers until it was used at the plant.

\subsection{Analytical Reagents}

All acids that were used for the analysis of mercury were trace-metal-grade. Other chemicals that were used in the preparation of analytical reagents were analytical-reagent-grade. The calibration standards used for instrument calibration and the QC standards used for calibration verification were purchased commercially and certified to be accurate within $\pm 0.5 \%$ and were traceable to National Institute of Standards and Technology Standard Reference Materials.

\subsection{Blanks}

As part of the QA/QC procedures, both a reagent blank and a field blank were done. A field blank is defined as a complete impinger train, including all glassware and solutions, that is taken out to the field during sampling and exposed to ambient conditions. These sample trains are then taken apart and the solutions recovered and analyzed in the same manner as those sample trains used for sampling activities. 
If the field blank shows contamination above instrument background, steps must be taken to eliminate or reduce the contamination to below background levels. However, in all cases, the fields blanks and the reagent blanks taken during the sampling activities at the Valmont Station were shown below detection limits, as shown in Tables 21 and 22.

All acids, chemical reagents, and deionized water used for mercury determination were analyzed for background levels of mercury. Each time a new batch of reagents was prepared, an aliquot was immediately taken and analyzed for mercury. Again, no mercury contamination was found.

TABLE 21

Reagent Blank Analysis Results

\begin{tabular}{lc}
\hline & $\begin{array}{c}\text { Unit } 1 \\
\text { Hg Solution, } \\
\boldsymbol{\mu g} / \mathbf{L}\end{array}$ \\
\hline $\mathrm{KCl}$ Reagent Blank & $<0.03$ \\
$\mathrm{H}_{2} \mathrm{O}_{2}$ Reagent & $<0.03$ \\
$\mathrm{KMnO}_{4}$ Reagent Blank & $<0.03$ \\
$5 \% \mathrm{KMnO}_{4}$ Blank & $<0.03$ \\
$10 \% \mathrm{HNO}_{3}$ Blank & $<0.03$ \\
$0.1 \mathrm{~N} \mathrm{HNO}_{3}$ & $<0.03$ \\
\hline
\end{tabular}

TABLE 22

Results of Mercury Speciation Field Blanks

\begin{tabular}{lccc}
\hline Sample & $\begin{array}{c}\text { KCl } \\
\text { Solution, } \\
\boldsymbol{\mu g} / \mathbf{L}\end{array}$ & $\begin{array}{c}\mathbf{H}_{2} \mathbf{O}_{2} \\
\text { Solution, } \\
\boldsymbol{\mu g} / \mathbf{L}\end{array}$ & $\begin{array}{c}\mathbf{K M n O}_{4} \\
\text { Solution, } \\
\boldsymbol{\mu g} / \mathbf{L}\end{array}$ \\
\hline Day 1 - Inlet & $<0.03$ & $<0.03$ & $<0.03$ \\
Day 1 - Outlet & $<0.03$ & $<0.03$ & $<0.03$ \\
Day 2- Inlet & $<0.03$ & $<0.03$ & $<0.03$ \\
Day 2 - Outlet & $<0.03$ & $<0.03$ & $<0.03$ \\
\hline
\end{tabular}




\subsection{Spiked Samples}

In order to ensure that adequate levels of accuracy were maintained, spiked samples were also submitted for analysis. These samples were made up independently of the chemist doing the analyses. The spikes were required to be within $15 \%$ of the true value. The spiking solutions were from a stock separate from the calibration standard stock. The analytical results for the spiked samples are shown in Table 23. All the spiked samples were within the tolerance specified.

\subsection{CONCLUSIONS}

On the basis of the results from the sampling program at the Valmont Station, the following conclusions can be made:

TABLE 23

Results of Mercury Speciation Field Spikes

\begin{tabular}{lcccc}
\hline Type & $\begin{array}{c}\text { Spike } \\
\text { Amount, } \\
\boldsymbol{\mu g} / \mathbf{L}\end{array}$ & $\begin{array}{c}\text { Sample } \\
\text { Value, } \\
\boldsymbol{\mu g} / \mathbf{L}\end{array}$ & $\begin{array}{c}\text { Spike } \\
\text { Reading, } \\
\boldsymbol{\mu g} / \mathbf{L}\end{array}$ & $\begin{array}{c}\text { Spike } \\
\text { Recovery, } \\
\mathbf{\%}\end{array}$ \\
\hline $\mathrm{KCl}$ & 5 & $<0.03$ & 5.14 & 102.8 \\
$\mathrm{KCl}$ & 10 & $<0.03$ & 9.83 & 98.3 \\
$\mathrm{KCl}$ & 5 & 0 & 5.53 & 110.6 \\
$\mathrm{KCl}$ & 10 & $<0.03$ & 10.56 & 105.6 \\
$\mathrm{KCl}$ & 5 & $<0.03$ & 5.3 & 106.0 \\
$\mathrm{KCl}$ & 10 & 5.3 & 16.1 & 108.0 \\
$\mathrm{KCl}$ & 5 & $<0.03$ & 5.48 & 109.6 \\
$\mathrm{KCl}$ & 10 & 5.48 & 16.1 & 106.2 \\
$\mathrm{KCl}$ & 5 & $<0.03$ & 5.73 & 114.6 \\
$\mathrm{KCl}$ & 10 & $<0.03$ & 10.51 & 105.1 \\
$\mathrm{H}_{2} \mathrm{O}_{2}$ & 5 & $<0.03$ & 4.97 & 99.4 \\
$\mathrm{H}_{2} \mathrm{O}_{2}$ & 10 & $<0.03$ & 10.61 & 106.1 \\
$\mathrm{H}_{2} \mathrm{O}_{2}$ & 2 & $<0.03$ & 1.74 & 87.0 \\
$\mathrm{H}_{2} \mathrm{O}_{2}$ & 10 & 1.74 & 12.95 & 112.1 \\
$\mathrm{H}_{2} \mathrm{O}_{2}$ & 5 & $<0.03$ & 4.52 & 90.4
\end{tabular}




\begin{tabular}{lcccc}
$\mathrm{H}_{2} \mathrm{O}_{2}$ & 10 & 4.52 & 14.72 & 102.0 \\
$\mathrm{KMnO}_{4}$ & 5 & 0.26 & 5.56 & 106.1 \\
$\mathrm{KMnO}_{4}$ & 5 & $<0.03$ & 4.73 & 94.6 \\
$\mathrm{KMnO}_{4}$ & 5 & $<0.03$ & 9.98 & 105.0 \\
$\mathrm{KMnO}_{4}$ & 5 & 5.05 & 5.05 & 101.0 \\
$\mathrm{KMnO}_{4}$ & 5 & 0 & 10.30 & 105.0 \\
& & Average & 103.6 \\
& & Std. Dev. & 6.8 \\
\hline
\end{tabular}

- The mercury emissions (stack) from UnitV5 at the Valmont Station are very low, $>0.2 \mu \mathrm{g} / \mathrm{Nm}^{3}$.

- The baghouse captured $\sim 85 \%$ of the total mercury generated and over $95 \%$ of the particulatebound mercury and $\mathrm{Hg}^{0}$.

- The Semtech Hg 2000/2010 results were not very good because of the very low mercury concentrations at the stack. However, the PS Analytical Sir Galahad and Tekran gave total mercury results very comparable to those obtained using the Ontario Hydro mercury speciation sampling method.

- The total mercury emission factors, based on the coal feed rate, was only $0.17 \pm 0.15 \mathrm{lb} / 10^{12}$ Btu. This compares very well to emission factors calculated based on $F_{D}$ factors as outlined in EPA Method, $0.12 \pm 0.05 \mathrm{lb} / 10^{12}$ Btu.

- Because the mercury concentrations were so low, the overall mercury balances were variable: the overall average mercury balance was $118.3 \%$. The mercury balance across the baghouse was $70.5 \%$.

- The chloride concentration in the flue gas was very low, as is the case with all western coals.

- The multicyclone data indicated that mercury preferentially adsorbs on the fine particulate.

- The fly ash generated at the Valmont Station results in mercury being adsorbed across the filter of the $\mathrm{OH}$ sampling method at the inlet of the baghouse. This adsorption was greatly reduced using a multicyclone rather than a filter.

- The sampling results indicate that the Valmont Station should be able to meet almost any mercury regulation that would be proposed without any changes to the system. 


\subsection{REFERENCES}

1. U.S. Environmental Protection Agency. Mercury Study Report to Congress; Airlink Web Site at http://www.epa.gov/airlinks/.

2. U.S. Environmental Protection Agency. Study of Hazardous Air Pollutant Emissions from Electric Utility Steam Generating Units; Airlink Web Site at http://www.epa.gov/airlinks/.

3. Information Collection Request; http://rti.org/part3/summaryP3.cfm.

4. Battelle. A Study of Toxic Emissions from a Coal-Fired Power Plant Utilizing and ESP/Wet FGD System; final report for U.S. DOE Contract DE-AC22-93PC-93251; July 1994.

5. Laudal, D.L.; Heidt, M.K. Evaluation of Flue Gas Mercury Speciation Methods; EPRI Report No. TR-108988; Dec 1997.

6. Sun, J.; Lillemoen, C.; Crocker, C. The Effect of Coal Combustion Flue Gas Components on Low-Level Chlorine Speciation Using EPA Method 26A; Energy \& Environmental Research Center; submitted for publication to Journal of the Air \& Waste Management Association, Feb 2000.

7. Laudal, D.L.; Thompson, J.S. Mercury Speciation Sampling at Great River Energy's Stanton Station; final report for U.S. Department of Energy Contract No. DE-FC26-98FT-40321; March 2000.

8. Carey, T. R.; Hargrove, O.W., Jr.; Richardson, C. F.; Chang R.; Meserole, F.B. Factors Affecting Mercury Control in Utility Flue Gas Using Sorbent Injection. Presented at the Air \& Waste Management Association 90th Annual Meeting \& Exhibition, June 1997, Toronto, ON, Canada; Paper No. 97-WA72A.05.

9. Laudal, D.L.; Thompson, J.S. Mercury Speciation Sampling for the ICR at Public Service Company of Colorado Valmont Station; Final Report for U.S. Department of Energy Contract No. DE-FC26-98FT40321, Public Service Company of Colorado, and EPRI; EERC Publication 2000-EERC-01-10; Energy \& Environmental Research Center: Grand Forks, ND, Feb 2000. 
APPENDIX A

\section{EXAMPLES OF CALCULATIONS USED IN THE REPORT}




\section{Sample calculations}

Sample calculations are included for each of the calculated parameters. Data from the inlet location during Run 1 were used with data from the stack location from Run 1 where necessary.

\section{Volume of Gas Sample}

$\mathrm{Vm}(\mathrm{std}) \quad$ = Volume of gas sample measured by the dry gas meter, corrected to standard conditions, dscf

$\mathrm{Vm}(\mathrm{std})(\mathrm{dscf}) \quad=\mathrm{K}_{1} * \mathrm{Vmc} * \mathrm{Pm} /(\mathrm{Tm}+460)$

$\mathrm{Vm}(\mathrm{std}) \quad=17.64 * 67.040 * 1 * 25.058 /(101+460)=52.822 \mathrm{dscf}$

Where:

$\mathrm{K}_{1} \quad=17.64 \mathrm{ER} / \mathrm{in} . \mathrm{Hg}$

$\mathrm{Vmc} \quad=\mathrm{Vm} * \mathrm{Cm}=$ Volume of gas sample as measured by dry gas meter corrected for meter calibration $(\mathrm{Cm}=$ meter calibration coefficient $)(\mathrm{dcf})$

Pm = Meter pressure (in. $\mathrm{Hg})$

$\mathrm{Tm}=$ Meter temperature $(\mathrm{EF})$

Volume of Water Vapor

Vw(std) $\quad=$ Volume of water vapor in the gas sample, corrected to standard conditions, scf
$\begin{aligned} & \mathrm{Vw}(\mathrm{std})(\mathrm{scf}) \quad \mathrm{K}_{2} * \mathrm{H}_{2} \mathrm{O}(\mathrm{g}) \\ & \mathrm{Vw}(\mathrm{std}) \quad= \\ & 0.04715 * 148.6=7.006 \mathrm{scf}\end{aligned}$

Where:

$\mathrm{K}_{2} \quad=0.04715 \mathrm{ft}^{3} / \mathrm{g}$

$\mathrm{H}_{2} \mathrm{O}(\mathrm{g}) \quad$ = Mass of liquid collected in impingers and silica gel $(\mathrm{g})$ 


\section{Water Vapor in the Gas Stream}

$\begin{array}{ll}\text { Bws } & =\text { Water vapor in the gas stream, proportion by volume } \\ \text { Bws } & =\mathrm{Vw}(\mathrm{std}) /(\mathrm{Vm}(\mathrm{std})+\mathrm{Vw}(\mathrm{std})) \\ \text { Bws } & =7.006 /(52.822+7.006)=0.1171\end{array}$

\section{Dry Molecular Weight}

Md = Dry molecular weight of stack gas, lb/lb-mole

$\mathrm{Md}(\mathrm{lb} / \mathrm{lb}-\mathrm{mole}) \quad=0.440 *\left(\% \mathrm{CO}_{2}\right)+0.320 *\left(\% \mathrm{O}_{2}\right)+0.280 *\left(\% \mathrm{~N}_{2}+\% \mathrm{CO}\right)$

Md $\quad=0.440 * 14.2+0.320 * 5.4+0.280 * 80.5=30.5 \mathrm{lb} / \mathrm{lb}-\mathrm{mole}$

Where:

$\%\left(\mathrm{CO}_{2}, \mathrm{O}_{2}, \mathrm{~N}_{2}, \mathrm{CO}\right)=$ Percent $\left(\mathrm{CO}_{2}, \mathrm{O}_{2}, \mathrm{~N}_{2}, \mathrm{CO}\right)$ by volume, dry basis

\section{Molecular Weight}

Ms = Molecular weight of stack gas, wet basis, lb/lb-mole

$\operatorname{Ms}(\mathrm{lb} / \mathrm{lb}-\mathrm{mole}) \quad=\operatorname{Md} *(1 ! \mathrm{Bws})+18.0 * \mathrm{Bws}$

Ms $\quad=30.5 *(1 ! 0.1171)+18.0 * 0.1171=29.0 \mathrm{lb} / \mathrm{lb}-\mathrm{mole}$

\section{Average Stack Gas Velocity}

Vs $\quad=$ Average stack gas velocity, $\mathrm{ft} / \mathrm{sec}$

Vs $\left.(\mathrm{ft} / \mathrm{sec}) \quad=\mathrm{K}_{3} * \mathrm{Cp} *() \mathrm{p}\right)^{1 / 2} \operatorname{avg} *[(\mathrm{Ts}+460) /(\mathrm{Ps} * \mathrm{Ms})]^{1 / 2}$

Vs $\quad=85.49 * 0.84 * 0.537 *[(288+460) /(24.44 * 29.0)]^{1 / 2}=39.6 \mathrm{ft} / \mathrm{sec}$

Where: 


$$
\begin{array}{ll}
\mathrm{K}_{3} & =85.49 \mathrm{ft} / \mathrm{sec}\left[(\mathrm{lb} / \mathrm{lb}-\mathrm{mole})(\mathrm{in} . \mathrm{Hg}) /\left((\mathrm{ER})\left(\mathrm{in} . \mathrm{H}_{2} \mathrm{O}\right)\right)\right]^{1 / 2} \\
\mathrm{Cp} & =\text { Pitot tube coefficient, dimensionless } \\
) \mathrm{p} & =\text { Velocity head of stack gas (in. } \mathrm{Hg}) \\
\mathrm{Ts} & =\text { Stack gas temperature }(\mathrm{EF}) \\
\text { Ps } & =\text { Stack pressure (in. } \mathrm{Hg})
\end{array}
$$

\section{Isokinetic Sampling Rate}

I

I $(\%)$

I

Where:

$\mathrm{K}_{4}$

An

2
$=$ Percent of isokinetic sampling, $\%$

$=\mathrm{K}_{4} *(\mathrm{Ts}+460) * \mathrm{Vm}(\mathrm{std}) /(\mathrm{Ps} * \mathrm{Vs} * \mathrm{An} / 144 * 2 *(1 ! \mathrm{Bws}))$

$=0.09450 *(288+460) * 52.822 /(24.44 * 39.6 * 0.0539 / 144 * 120 *$ $(1 ! 0.1171))=97 \%$

$=0.09450 \%($ in. $\mathrm{Hg})(\mathrm{min}) /((\mathrm{ER})(\mathrm{sec}))$

$=$ Cross-sectional area of nozzle $\left(\right.$ in. $\left.^{2}\right)$

$=$ Total sampling time $(\mathrm{min})$

Volume of Gas Sample Corrected to $3 \% \mathrm{O}_{2}$

$\mathrm{Vm} *(\mathrm{std})$

$=$ Volume of gas sample measured by the dry gas meter $(\mathrm{Vm}(\mathrm{std})), *$ corrected to $3 \%$ oxygen, $\mathrm{Nm}^{3}$

$\mathrm{Vm} *(\mathrm{std})$

$=\mathrm{Vm}(\mathrm{std}) *\left(21 ! \% \mathrm{O}_{2}\right) / 18 * \mathrm{~K}_{5}$

$\mathrm{Vm} *(\mathrm{std})$

$=52.822 *(21 ! 5.35) / 18 * 0.02832=1.301 \mathrm{Nm}^{3}$

Where:

$\mathrm{K}_{5}$

$=0.02832 \mathrm{~m}^{3} / \mathrm{ft}^{3}$ 


\section{Mercury}

\begin{tabular}{|c|c|}
\hline $\mathrm{Hg}(\mu \mathrm{g})$ & $=\mu \mathrm{g} / \mathrm{g} * \mathrm{~g}$ or $\mu \mathrm{g} / \mathrm{L} * \mathrm{~mL} / 1000$ \\
\hline $\mathrm{Hg}$ & $=0.138 * 8.65225=1.19 \mu \mathrm{g}$ (using the particulate mercury data from Run 1$)$ \\
\hline $\mathrm{Hg}\left(\mu \mathrm{g} / \mathrm{Nm}^{3}\right)$ & $=\mu \mathrm{g} / \mathrm{Vm} *(\mathrm{std})$ \\
\hline $\mathrm{Hg}$ & $=1.194 / 1.301=0.92 \mu \mathrm{g} / \mathrm{Nm}^{3}$ \\
\hline Particulate $\mathrm{Hg}$ & $\begin{array}{l}=\text { Sum of mercury from filter and nozzle rinse (note: all nozzle rinse values were } \\
\text { nondetects) }\end{array}$ \\
\hline Oxidized $\mathrm{Hg}$ & $=$ Sum of mercury from $\mathrm{KCl}$ impingers \\
\hline Elemental Hg & $\begin{array}{l}=\text { Sum of mercury from } \mathrm{H}_{2} \mathrm{O}_{2} \text { and } \mathrm{KMnO}_{4} \text { impingers (note: all } \mathrm{H}_{2} \mathrm{O}_{2} \text { impinger } \\
\text { values were nondetects). Since typically less than } 5 \% \text { of the elemental mercury } \\
\text { is trapped in the } \mathrm{H}_{2} \mathrm{O}_{2} \text { impinger, the less than values were not added to the total } \\
\text { elemental mercury. Thus the elemental mercury was calculated from the values } \\
\text { obtained from the } \mathrm{KMnO}_{4} \text { impingers only. }\end{array}$ \\
\hline
\end{tabular}

\section{Mass Rates}

$\mathrm{Hg}(\mathrm{lb} / \mathrm{hr})$ from coał $\mathrm{Cf} *(1 ! \mathrm{Bc}) * \mathrm{Hg}(\mathrm{ppm}) / 10^{6}$

$\mathrm{Hg}(\mathrm{lb} / \mathrm{hr})$ from coa $155,968 *(1 ! 0.1610) * 0.010 / 10^{6}=0.0013 \mathrm{lb} / \mathrm{hr}$

Where:

Cf $\quad=$ Coal feed rate $(\mathrm{lb} / \mathrm{hr})$

$\mathrm{Hg}(\mathrm{ppm}) \quad$ = Mercury concentration in coal (ppm, dry)

$\mathrm{Bc} \quad=$ Coal moisture (fraction)

$\mathrm{Hg}(\mathrm{lb} / \mathrm{hr})$ in flue gas $=\mathrm{Hg}\left(\mu \mathrm{g} / \mathrm{Nm}^{3}\right) * \mathrm{Sf} *\left(21 ! \% \mathrm{O}_{2}\right) / 18 *(1 ! \mathrm{Bws}) * \mathrm{~K}_{6}$

$\mathrm{Hg}(\mathrm{lb} / \mathrm{hr})$ in flue gas $=1.214 * 422,604 *(21 ! 5.35) / 18 *(1 ! 0.1171) * 3.745 \times 10^{-9}=$ $0.0015 \mathrm{lb} / \mathrm{hr}$

Where: 
$\mathrm{K}_{6}$

Sf

$=3.745 \times 10^{-9}(\mathrm{lb} / \mu \mathrm{g})(\mathrm{m} / \mathrm{hr})\left(\mathrm{m}^{3} / \mathrm{ft}^{3}\right)$

$=$ Stack gas flow (scfm) 


\section{Emission Rate}

$\begin{aligned} \mathrm{Hg}\left(\mathrm{lb} / 10^{12} \mathrm{Btu}\right) & =\mathrm{Hg}\left(\mu \mathrm{g} / \mathrm{Nm}^{3}\right) * \mathrm{Sf} *(1 ! \mathrm{Bws}) *\left(21 ! \% \mathrm{O}_{2}\right) / 18 / \mathrm{Cf} / \mathrm{Hv} * \mathrm{~K}_{7} \\ \mathrm{Hg}\left(\mathrm{lb} / 10^{12} \mathrm{Btu}\right) & =1.214 * 422,604 *(1 ! 0.1171) *(21 ! 5.35) / 18 / 155,968 / 10,317 * 3745 \\ & =0.92 \mathrm{lb} / 10^{12} \mathrm{Btu}\end{aligned}$

Where:

$\mathrm{K}_{7}=3745\left(\mathrm{~m}^{3} / \mathrm{ft}^{3}\right)(\mathrm{m} / \mathrm{hr})(\mathrm{lb} / \mu \mathrm{g})\left(\mathrm{Btu} / 10^{12} \mathrm{Btu}\right)$

$\mathrm{Hv} \quad=$ Heating value $(\mathrm{Btu} / \mathrm{lb})$ 